\title{
The Arctic Carbon Cycle and Its Response to Changing Climate
}

\author{
Lori Bruhwiler $^{1}$ (D) $\cdot$ Frans-Jan W. Parmentier ${ }^{2,3}$ (D) Patrick Crill ${ }^{4}$ (D) Mark Leonard $^{1,5} \cdot$ Paul I. Palmer $^{6}$ (D)
}

Accepted: 26 November 2020 / Published online: 2 February 2021

(C) This is a U.S. government work and not under copyright protection in the U.S.; foreign copyright protection may apply 2021

\begin{abstract}
Purpose of Review The Arctic has experienced the most rapid change in climate of anywhere on Earth, and these changes are certain to drive changes in the carbon budget of the Arctic as vegetation changes, soils warm, fires become more frequent, and wetlands evolve as permafrost thaws. In this study, we review the extensive evidence for Arctic climate change and effects on the carbon cycle. In addition, we re-evaluate some of the observational evidence for changing Arctic carbon budgets.

Recent Findings Observations suggest a more active $\mathrm{CO} 2$ cycle in high northern latitude ecosystems. Evidence points to increased uptake by boreal forests and Arctic ecosystems, as well as increasing respiration, especially in autumn. However, there is currently no strong evidence of increased CH4 emissions.

Summary Long-term observations using both bottom-up (e.g., flux) and top-down (atmospheric abundance) approaches are essential for understanding changing carbon cycle budgets. Consideration of atmospheric transport is critical for interpretation of top-down observations of atmospheric carbon.
\end{abstract}

Keywords Arctic $\cdot$ Climate change $\cdot$ Carbon cycle $\cdot$ Permafrost $\cdot$ Methane

\section{Introduction-a Review of Arctic Change and the Carbon Cycle}

\section{Arctic Climate Change}

In recent decades, the Arctic mean annual surface temperature has increased at over twice the rate of the global average $[1,2]$. This polar amplification of surface air temperature is due to a combination of surface albedo feedbacks

This article is part of the Topical Collection on Arctic Climate Change

Lori Bruhwiler

lori.bruhwiler@noaa.gov

NOAA Global Monitoring Laboratory, Boulder, CO, USA

2 Department of Geosciences, University of Oslo, Oslo, Norway

3 Department of Physical Geography and Ecosystem Science, Lund University, Lund, Sweden

4 Department of Geological Sciences and Bolin Centre for Climate Research, Stockholm University, Stockholm, Sweden

5 Cooperative Institute for Research in Environmental Sciences, University of Colorado, Boulder, CO, USA

6 School of GeoSciences, University of Edinburgh, Edinburgh, UK due to losses in snow and sea ice cover, cloud-sea ice interactions, lapse-rate change feedback, increased northward transport of heat and moisture, and increasing cloudiness and atmospheric water vapor, but the importance of these individual processes is unclear [3-9]. Arctic surface air temperatures over 2014-2019 have exceeded all previous years in the observational record going back to 1900 [2]. Winter surface air temperatures are warming most rapidly; e.g., during the winters of 2016 and 2018, temperatures were $6{ }^{\circ} \mathrm{C}$ above the 1981-2010 average [1]. In 2019, winter surface air temperatures in the Alaskan sector of the Arctic were $4{ }^{\circ} \mathrm{C}$ above the baseline period of $1981-2010$ [2]. Box et al. [10] used the NCEP/NCAR reanalysis to show that temperature has been increasing at $0.7^{\circ} \mathrm{C} /$ decade during the Arctic cold season and more slowly during the warm season, $0.4{ }^{\circ} \mathrm{C} /$ decade. Arctic climate change has been linked to anthropogenic radiative forcing [11], and Najafi et al. [12] showed using CMIP5 climate models that anthropogenic aerosols could have offset a significant amount of warming that would otherwise have occurred.

Arctic sea ice has markedly declined with the annual minimum extent in September decreasing by 13\% per decade between 1979 and 2018 [1, 13]. Multi-year ice coverage (> 5 years old) decreased to less than $2 \%$ of winter sea ice area by $2018[14,15]$ and sea ice is thinning over time [1]. These 
reductions are unprecedented since the fourteenth century [16]; Notz and Stroeve [17] directly linked these changes to anthropogenic carbon emissions. The Arctic Ocean may become ice-free during summer months by the middle of the twenty-first century unless anthropogenic emissions are significantly decreased [18]. Lack of sea ice results in increased absorption of solar radiation by surface ocean waters and, combined with transport of heat from lower latitudes, Arctic Ocean heat content is increasing and summer mixed layer temperatures are increasing by $0.5^{\circ} \mathrm{C} /$ decade $[1,19,20]$.

Terrestrial snow cover extent is also decreasing as the Arctic warms. Mudryk et al. [21] found a strong link between warming air temperature and reduction of snow cover extent. Using multiple data sets, they showed that losses in snow cover extent are greatest in autumn and spring. The trend in snow cover extent (1981-2019) during May is - 3.4\%/decade and $-15.2 \%$ /decade for June [22]. The duration of snow cover has also decreased over the past several decades by $2-4$ days/ decade [23]. Estimates of maximum snow depth-averaged over the pan-Arctic region are also showing declines over the past $\sim 4$ decades as well as shifts from frozen to liquid precipitation in relatively warmer coastal and low altitude environments [23]. Precipitation in the Arctic is also increasing [24]. Using the NCEP/NCAR Reanalysis covering 1971 to 2017, Box et al. [10] found that cold season (October-May) precipitation north of $50^{\circ} \mathrm{N}$ increased by almost $7 \%$, and by nearly $5 \%$ during the warm season. An analysis of weather station observations by Wendler et al. [25] found a $17 \%$ increase in precipitation for Alaska over the past 67 years, with decadal variability affected by the phase of the Pacific Decadal Oscillation. As precipitation and temperature increased, so have evapotranspiration and river runoff into the Arctic Ocean [10, 26, 27]. Increased river discharge results in increased nutrient and organic carbon input to the Arctic Ocean and freshening of ocean water. Increased precipitation will not necessarily lead to increased soil moisture, however, since the evolution of soil moisture will depend on the balance between precipitation and evapotranspiration [28] as well as drainage from Arctic soils.

Arctic hydrology is strongly influenced by the presence of permafrost and subsurface ice. Permafrost underlies about $25 \%$ of the Northern Hemisphere land surface [29]. Biskaborn et al. [29] used borehole observations distributed throughout the Arctic from the Global Terrestrial Network for Permafrost to quantify temperature changes over 2007-2016 for the depth at which the annual soil temperature variation is zero. They found that soil temperatures at sites with continuous permafrost have increased over this period by about $0.4{ }^{\circ} \mathrm{C}$, with smaller increases in discontinuous permafrost zones $\left(0.2^{\circ} \mathrm{C}\right)$. Liljedahl et al. [30] examined the role of subsurface ice-wedge evolution in reducing inundation and increasing runoff in tundra permafrost regions. Subsidence by thawing permafrost can lead to formation of new shallow lakes and ponds [31,32], and about $20 \%$ of the Arctic land surface is covered by this thermokarst landscape. Ice-wedge thawing can lead to drainage of tundra soils, and thawing of permafrost along slopes and coastlines can lead to slumping, increased runoff, and transfer of organic material into rivers and the Arctic Ocean [33, 34]. The evolution of soil hydrology has important implications for the carbon balance of the Arctic since wetter environments rich in organic material favor anaerobic respiration that results in slower soil carbon remineralization and increased methane emissions relative to aerobic respiration. Using Landsat imagery for 1999 to 2014, Nitze et al. [33] found that lake area decreased by $1.4 \%$ for the region covered by their continental scale transects. The largest losses were found in regions of discontinuous permafrost, while in the continuous permafrost zone, some regions had expanding lake area and some had decreasing lake area. Other studies found increasing lake areas due to initiation of permafrost thaw $[35,36]$. As permafrost thaws, the column of overlying soil that freezes during the cold season and thaws during the warm season (the Active Layer Zone; [37]) deepens and more soil carbon is available for efficient remobilization to the atmosphere where it can contribute to further warming, an effect known as the "permafrost carbon feedback". Chang et al. [38] showed that a complication for modeling regional ALD is bias and non-representativeness of driving climate data and that this source of uncertainty can be as large as that due to unresolved spatial heterogeneity of soil hydrology and permafrost distribution.

An enormous amount of carbon is stored in Arctic soils, with estimates ranging from 1137 to $1850 \mathrm{PgC}$ [40-41] including deep soils, and an unknown amount of carbon in subsea sediments [42]. Surface permafrost carbon (0-3-m depth) is estimated to contain $1035 \pm 150 \mathrm{PgC}$ [41], a significant amount of soil carbon considering that the permafrost region covers roughly $20 \%$ of global exposed land area and that total global soil carbon is around $3100 \mathrm{PgC}$ [42]. Tarnocai et al. [40] point out that the northern permafrost region may account for about $50 \%$ of global soil organic carbon.

Submerged relic permafrost exists along shallow continental shelves, especially in the Laptev Sea. This subsea permafrost was formed when the sea level was much lower during the last glacial period [43]. Models of subsea permafrost indicate the possible continued presence of subsea permafrost and stability of intra-permafrost gas hydrates [44]. Over many centuries, it is possible that these sediments will thaw as sea surface temperatures rise [45], and Ferré et al. [46] showed that even small temperature increases could lead to destabilization of hydrates. However, this in itself is not guaranteed to lead to significant carbon emissions since other factors, such as sediment permeability must also be factored in [47].

Vegetation has also been changing in response to changing Arctic climate [48-50]. Changes in vegetation over the last several decades have been inferred from comparison of 
satellite observations of surface reflectance of near-infrared light, which is reflected by vegetation, and red light, which is absorbed by vegetation. This difference is known as the normalized difference vegetation index (NDVI). Maximum summer values of NDVI have been increasing across the Arctic ("greening", [51]), especially for 1982-1998, likely due to longer growing seasons, warmer temperatures, and a more intense hydrological cycle. From 1999 to 2015, some regions exhibit negative ("browning") trends, which also shows up in NDVI integrated over the growing season. Although peak summertime productivity has been increasing, during other periods of the growing season, increases are not as prominent and in recent years do not occur for the entire Arctic. NDVI changes could be interpreted as an expansion of woody vegetation, such as shrubs, and disturbance in the case of browning. However, Myers-Smith [52] highlighted some of the complexities in interpretation of vegetation index data. Standing water, snow cover, and soil moisture can influence surface reflectance of vegetated land. Vegetation indices can also be nonlinear with vegetation biomass so that they become more or less sensitive to changes over time with vegetation changes. Myers-Smith et al. [52] also highlighted the fact that spatial heterogeneity of Arctic vegetation and lack of coverage of in situ data make it difficult to compare changes in satellite vegetation indices directly with ground observations.

Biomass burning is an important disturbance in boreal ecosystems, and more frequently in tundra regions. Large amounts of carbon can be quickly released into the atmosphere from both above-ground biomass and soil organic matter. Over 1997-2016, van der Werf et al. [53] found emissions of $\mathrm{CO}_{2}$ from fires to average $185 \mathrm{TgC} /$ year with minimum and maximum yearly emissions of 57 and $408 \mathrm{TgC} /$ year. Emissions of $\mathrm{CH}_{4}$ are a small fraction of this amount since the $\mathrm{CO}_{2}$ emission factor is 250 times larger than that of $\mathrm{CH}_{4}$ for boreal forests and 81 times larger for peat fires which tend to smolder and produce reduced carbon such as $\mathrm{CH}_{4}$. Combustion of moss, peat, and litter were found to make up $85 \%$ of total combusted fuels for Canadian forest fires [54], and removal of this surface insulating layer can affect soil respiration and permafrost stability with further implications for soil hydrology [55, 56]. Turetsky et al. [57] demonstrated that late season, upland fires burn deeper and longer, sometimes even for multiple years, into the ground-layer than wetter peatland and permafrost environments. 2019 was a severe fire year across Siberia and Alaska, with record-breaking heat, and fires may have continued to burn deep in peat soils over the cold season and break out again during the 2020 warm season. These holdover fires, also known as "zombie fires," have been observed in the Arctic in recent years and could accelerate permafrost loss and carbon emissions ([58]; https:// phys.org/news/2020-05-scientists-zombie-arctic.html). Indeed, 2019 and 2020 both appear to be record-setting years for $\mathrm{CO}_{2}$ emissions from fires north of the Arctic Circle (https://www.economist.com/graphic-detail/2020/09/07/thisyears-arctic-wildfires-are-the-worst-on-record-again, https:// phys.org/news/2020-09-co2-emissions-arctic-wildfires-eu. $\mathrm{html})$. After a burn, it can take many decades for recovery with possible changes to entirely different types of vegetation than were there initially $[59,60]$, for example, a transition from needleleaf to deciduous trees.

An analysis of Canadian forests by Coops et al. [61] found no long-term trend in burned area from 1985 to 2015; however, a trend towards an increasing area burned since 2006 was noted. Ponomarev et al. [62] found an increasing number of fires and burned area over recent decades for a transect in Siberia. However, there is large interannual variability in burned area, so longer records are needed to obtain clarity on trends. Satellite burned area products have been available since the late 1990s, and small but not statistically significant increases in area burned were found by Andela et al. [63]. Lightning is the most common ignition source for high-latitude fires, and Veraverbeke et al. [64] showed evidence for increasing lightning ignition between 1975 and 2015 for the Northwest Territories and Interior Alaska.

\section{The Future of Arctic Climate}

Past emissions and long lag times in ocean response mean that changes in Arctic climate will continue at least into the midtwenty-first century [23], longer if no climate mitigation occurs. Surface temperatures will continue to increase at about twice the rate as lower latitudes, and depending on future emissions, they could rise at another $4-5{ }^{\circ} \mathrm{C}$ above late 1990s' temperatures by the mid-twenty-first century. For high-emission scenarios, climate models (CMIP6) predict ice-free summers in the Arctic Ocean after the mid-twentyfirst century [65]. By the middle of the century, snow cover duration is expected to decrease by $10-20 \%$ from present-day [23]. Earlier snowmelt will have implications for summer soil moisture and fire ignition. Glaciers will continue to melt leading to increases in sea level rise, and more coastal erosion exacerbated by permafrost thaw and the loss of protective landfast sea ice [66]. The hydrologic cycle is expected to continue to intensify with $30-50 \%$ increases in winter precipitation over the ocean and increasing runoff from land. The CMIP5 climate model ensemble also suggests that extreme precipitation events will become more common as variability of precipitation increases due to changes in moisture transport from mid-latitudes, possibly linked to changes in modes of variability such as the Arctic Oscillation, and the Pacific Decadal Oscillation [67]. At the same time, more precipitation may fall as rain rather than snow with further implications for hydrology [68]. Evapotranspiration is expected to increase. For the worst-case high-emission scenario (e.g., Representative Concentration Pathway leading to a radiative 
forcing of $8.5 \mathrm{~W} \mathrm{~m}^{-2}$ (RCP8.5) [69]), CMIP5 models show that Arctic temperatures could soar above late-twentiethcentury levels by $13{ }^{\circ} \mathrm{C}$ in winter and $5{ }^{\circ} \mathrm{C}$ in summer [70].

In response to projected increases in Arctic air temperature, the CMIP5 models show significant changes to the Arctic permafrost distribution [23]. For RCP4.5, areas where discontinuous permafrost currently exists will disappear. For the highest emission scenario (RCP8.5), permafrost may only remain in the top $3 \mathrm{~m}$ of soils in the northernmost regions and at highest elevations. McGuire et al. [71] analyzed an ensemble of models with relatively detailed representations of permafrost and found that the model average suggests that $90 \%$ of near-surface $(<3 \mathrm{~m})$ permafrost will be lost by 2300 for RCP8.5. For RCP4.5, the models predict an average loss of $29 \%$. Models suggest that much of the permafrost area loss will occur by 2100 , but they do not include the effects of abrupt thaw and fires on permafrost, both processes that could lead to more widespread and rapid permafrost loss. Recent model simulations that include abrupt thaw suggest a three to twelvefold increase in the amount of carbon that may be affected, depending on emission scenario [72].

Fire and other disturbances are expected to increase in boreal regions and Arctic tundra [73, 74]. For RCP6.0, Young et al. [74] found that the area of tundra burned in Alaska could double. Walter Anthony et al. [75] project an increase in thaw lake area, an indicator of abrupt thaw, of over $50 \%$ for the high-emission RCP8.5 scenario. Decreases in snow cover and changes in drainage due to permafrost thaw can further dry Arctic ecosystems, leading to increased burning and changes in vegetation.

Vegetation in the Arctic is expected to change significantly in the future. A statistical approach associating climate and vegetation types and considering two distinct emission trajectories found that trees and shrubs are projected to cover 24 $52 \%$ of present-day tundra area by 2050, replacing current vegetation communities [76]. Expansion of woody vegetation into tundra regions may have additional effects that will feed back on climate through more evapotranspiration, albedo changes, and impacts on soil temperature [77]. Pearson et al. [76] argue that these effects could serve as positive feedbacks on regional Arctic climate.

\section{Effects of Changing Climate on the Carbon Cycle}

Arctic climate change will have important effects on the carbon cycle. Figure 1 summarizes schematically climate change and its effects on the carbon cycle. Currently, the Arctic Ocean is thought to be a small net carbon sink of 0.1-0.2 PgC/year [23]. Increased open water should result in increased $\mathrm{CO}_{2}$ uptake by the Arctic Ocean both due to physical gas exchange and increased marine productivity [78]. Freshwater input from rivers and melting ice could, however, change this picture. Increased freshwater could increase thermohaline stability

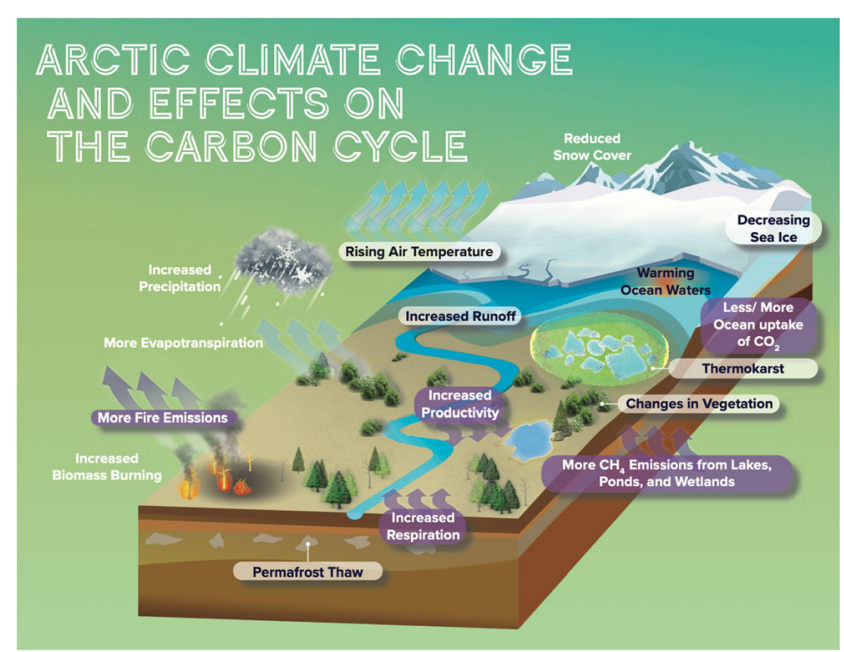

Fig. 1 Schematic illustrating Arctic climate change and its effects on the carbon cycle. Purple labels indicate carbon cycle responses. (Figure produced by S. Masais, NOAA Global Monitoring Laboratory)

inhibiting transfer of carbon from surface to deep waters, and nutrient loss from stratified surface waters could decrease productivity, thereby limiting the biological sink. Increased inputs of freshwater can reduce the buffering capacity of the Arctic Ocean and limit increased uptake of $\mathrm{CO}_{2}$ by delivering carbon to surface ocean waters. Export of carbon and nutrients from land to the Arctic Ocean can also increase productivity, especially in coastal regions [79].

Warming of ocean waters could lead to enhanced $\mathrm{CH}_{4}$ emissions from subsea permafrost and possibly destabilized hydrates. Shakhova et al. [80] estimated that $\sim 8 \mathrm{TgCH}_{4} /$ year is being emitted to the atmosphere from submerged hydrates in the subsea permafrost of the Laptev sea. However, emissions this large are not supported by atmospheric observations of $\mathrm{CH}_{4}$ abundance. Berchet et al. [81] found that emissions were likely to be less than half of that proposed by Shakhova et al. [80] and that atmospheric observations were more consistent with terrestrial or marine biosphere emissions rather than methane hydrates. Shipborne eddy covariance observations suggest $\sim 3 \mathrm{TgCH}_{4}$ /year for the Eastern Siberian Arctic Shelf [82], in agreement with Berchet et al. [81].

On land, longer growing seasons and higher temperatures are expected to drive increased productivity, and greening trends seen in NDVI data are consistent with this. However, many factors add to the complexity of how the terrestrial Arctic carbon cycle will change. Warming soils could drive an increase in respiration that partially offsets increases in productivity [83]. Long-term eddy covariance studies show that opposing fluxes of photosynthesis and respiration mostly cancel each other out, and changes in the net carbon balance are small $[84,85]$. Increases in precipitation and earlier snowmelt could affect soil moisture over the growing season, benefitting some plant communities while disadvantaging others. Expansion of woody plants into tundra regions will 
increase evapotranspiration [76], while thawing of permafrost could initially increase inundated areas due to subsidence leading to expanded methane-producing environments. In areas of discontinuous permafrost, drainage, encroachment of vegetation, and filling of shallower lakes will all have implications for carbon exchange $[35,86]$. With drier conditions and possibly increased ignition by lightning, fires could increase in the Arctic releasing built up carbon from organicrich soils [57].

The amounts of $\mathrm{CO}_{2}$ and $\mathrm{CH}_{4}$ emitted to atmosphere as permafrost thaws depend on the decomposability of organic matter stored in the soil and whether the decomposition occurs aerobically or anaerobically. Aerobic and anaerobic conditions are dependent on soil hydrology, which is susceptible to change as permafrost thaws [87]. As permafrost thaws, carbon release will initially increase rapidly as easily decomposed material is broken down leaving less labile carbon with slower release rates. Rates of carbon release are dependent on hydrological status, and field studies have shown considerable spatial variability in this over relatively small scales as shown by Chang et al. [38] who also pointed out that uncertainty in temperature and precipitation driving data could cause biases in $\mathrm{CO}_{2}$ and $\mathrm{CH}_{4}$ fluxes that are comparable to variability due to landscape heterogeneity. Methane is consumed in dry soil and oxic water columns $[88,89]$, and this must also be accounted for. In organic-rich, inundated environments, anaerobic respiration dominates, a slow process in comparison to aerobic respiration that leads to higher $\mathrm{CH}_{4}$ emissions. This is important because of the larger radiative impact of $\mathrm{CH}_{4}$ with a 100 -year global warming potential that is about 25 times greater than $\mathrm{CO}_{2}$ on a per mass basis [90]. Incubation studies show that aerobic respiration releases about 6 times the amount of carbon per year as anaerobic respiration ([42], see Fig. 2b). Abrupt permafrost thaw can lead to both formation and drainage of wetlands and small lakes, and the balance between lake/wetland formation and drainage determines whether aerobic or anaerobic decomposition dominates. The largest carbon emissions from permafrost regions could occur after present-day continuous permafrost has transitioned to discontinuous permafrost. Schuur et al. [42] estimated that $5-15 \%$ of permafrost could thaw by 2100. Assuming that $10 \%$ thaws over the next century, then 130-160 PgC could be vulnerable to thaw, although Turetsky et al. [91] project that $200 \mathrm{PgC}$ could be vulnerable by 2300 with another $60-100 \mathrm{PgC}$ vulnerable due to abrupt thaw. Models that include permafrost predict lower amounts of vulnerable carbon, $\sim 30-115 \mathrm{PgC}$ thawing by 2100 (e.g., [92]) likely because they do not include landscape changes such as those due to abrupt thaw and thermokarst formation. Schuur et al. [42] estimate that, assuming a constant release rate, $0.9 \pm$ $0.5 \mathrm{PgC} /$ year could be emitted into the atmosphere over the next century. If $2.3 \%$ of this is emitted as $\mathrm{CH}_{4}$ (e.g., [93]) then $28 \mathrm{TgCH}_{4} /$ year could be emitted as $\mathrm{CH}_{4}$. However, release of permafrost carbon will not be evenly distributed over the next century; rather, it will slowly increase with time into the twenty-second century unless $\mathrm{CO}_{2}$ emissions are significantly mitigated.

We have thus far documented the changing Arctic climate and its effect on the ecosystem and carbon emissions. Consideration of permafrost emissions aside, the current climate changes should have profound effects on carbon emissions in the Arctic. We therefore turn to the question of what changes in Arctic carbon emissions have been observed and whether they are attributable to specific processes.

\section{Observational Evidence for Carbon Cycle Changes at High Northern Latitudes}

\section{Current Understanding of Arctic Carbon Cycle Changes}

Some analyses of atmospheric observations have found changes in high-latitude $\mathrm{CO}_{2}$ fluxes. Graven et al. [94] used surface monitoring observations at Barrow, Alaska, and Mauna Loa, Hawaii, along with aircraft campaign observations to conclude that significant changes in the annual cycle of atmospheric $\mathrm{CO}_{2}(\sim 50 \%$ amplitude increase) occurred between 1958 and 1961 (campaigns associated with the International Geophysical Year) and 2009-2011 for latitudes north of $45^{\circ} \mathrm{N}$. They attributed these changes to an increase in $\mathrm{CO}_{2}$ uptake of 30-60\% mainly by boreal forests. Graven et al. [94] also found that the CMIP 5 models were unable to produce this large of an increase in terrestrial productivity. These findings were later confirmed by the annual cycle analysis of Barlow et al. [95] and similar conclusions were also reached by Forkel et al. [96]. Barlow et al. [95] showed that changes in the seasonal amplitude of atmospheric $\mathrm{CO}_{2}$ at Barrow from 1973 to 2015 were strongly correlated with trends in net carbon uptake during spring and summer months but had only a weak relationship with the net release of $\mathrm{CO}_{2}$ in autumn and winter months. They also showed that the start and end of the carbon uptake period have been getting earlier each year, but the length of the uptake period has remained comparatively constant, likely due to increased respiration. Collectively, these observations are consistent with northern latitude ecosystems progressively taking up more carbon during spring and summer months.

Atmospheric observations have shown that respiration from Arctic soils may also be increasing, at least for the North Slope region of Alaska. Commane et al. [98] used high-frequency observations from the Barrow Observatory to show that regional tundra emissions during the early cold season rose by $73 \%$ over 41 years, a response not captured by CMIP5 models. Further, they estimated that during 20122014, net emissions from tundra in Alaska dominated a small 
Fig. 2 Zonal average growth rate anomalies of $\mathrm{CO}_{2}$ (top, ppm/year) and $\mathrm{CH}_{4}$ (bottom, ppb/year) from the NOAA Global Greenhouse Gas Reference network. Warm colors represent higher than average atmospheric growth and cooler colors show slower than average atmospheric growth. Growth rate anomalies were calculated using observations from the NOAA Global Monitoring Laboratory's Greenhouse Gas Reference Network (https://www.esrl.noaa. gov/gmd/ccgg/)
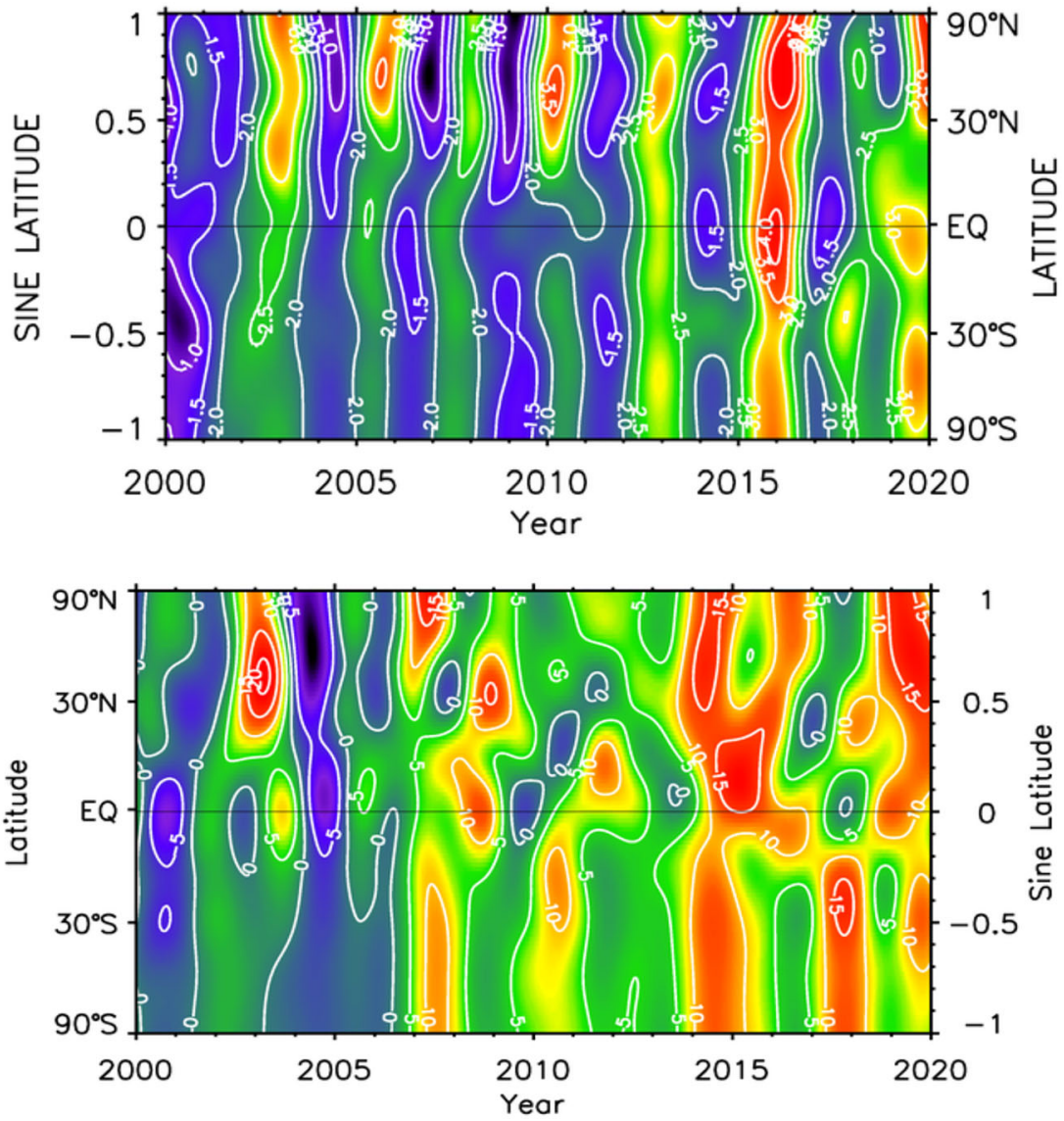

net uptake by boreal forest ecosystems, making Alaska a net carbon source during these years. Consistent with these results, Jeong et al. [99] used the long-term Barrow record of atmospheric $\mathrm{CO}_{2}$ and a carbon balance model to show that the carbon residence time in tundra ecosystems on the North Slope of Alaska has decreased by $\sim 13 \%$. They also proposed that increasing cold season soil carbon emissions could exceed warm season uptake making these ecosystems a net source of carbon to the atmosphere. Although long-term atmospheric records of $\mathrm{CO}_{2}$ seem to support changing $\mathrm{CO}_{2}$ fluxes, it is interesting that they do not yet indicate that $\mathrm{CH}_{4}$ emissions are increasing at least for the region near the Barrow Observatory on the North Slope of Alaska [100]. This can be explained if lake drainage and drying of wetlands reduced the area of methane emitting landforms.

\section{Insights from Global Atmospheric Observations}

Globally distributed, long-term monitoring observations of $\mathrm{CO}_{2}$ and $\mathrm{CH}_{4}$ in the atmosphere can provide information about the spatial and temporal distribution of fluxes. Figure 2 shows observed zonal average growth rate anomaly for both gases. Growth rates vary interannually with latitude and time, providing clues about the mechanisms of changing fluxes. However, atmospheric transport of lower latitude emissions must be taken into account to correctly interpret this information. Dlugokencky et al. [101] proposed that spatial gradient information like that shown in Fig. 2 could be used as a sensitive indicator of changing Arctic $\mathrm{CH}_{4}$ emissions, specifically by calculating the difference in measured mole fraction between zonally and annually averaged sites at northern $\left(53-90^{\circ} \mathrm{N}\right)$ and southern $\left(53-90^{\circ} \mathrm{S}\right)$ latitudes. This interpretation of the $\mathrm{CH}_{4}$ observations could be possible in part because the high latitudes of the Southern Hemisphere have no known significant sources or sinks of $\mathrm{CH}_{4}$ except for photochemical loss in the atmosphere which is relatively small at polar latitudes. Dlugokencky et al. [101] referred to this difference as the "interpolar difference" (IPD). They noted a decrease between the IPD prior to 1991 and afterwards (Fig. 3) and attributed this difference to the collapse of the Soviet Union and subsequent reduction in oil and gas leaks due to infrastructure investments by the Russian gas industry. Dlugokencky et al. [102] concluded that the existing longterm measurement network could detect changes in Arctic emissions of at least $10 \mathrm{TgCH}_{4} /$ year.

Implicit in the IPD is the assumption that signals from changes in emissions and sinks outside of the Arctic are transported equally to the polar latitudes of both hemispheres within the same calendar year (the IPD is an annually averaged quantity). Tropospheric interhemispheric transit times 
Fig. 3 The interpolar difference calculated as the difference between observed average $\mathrm{CH}_{4}$ at sites between 53 and $90^{\circ} \mathrm{N}$ and 53-90 $\mathrm{S}$ (update of [102]). The dashed lines represent linear leastsquares fits to the values in 1984 1991 and 1992-2019

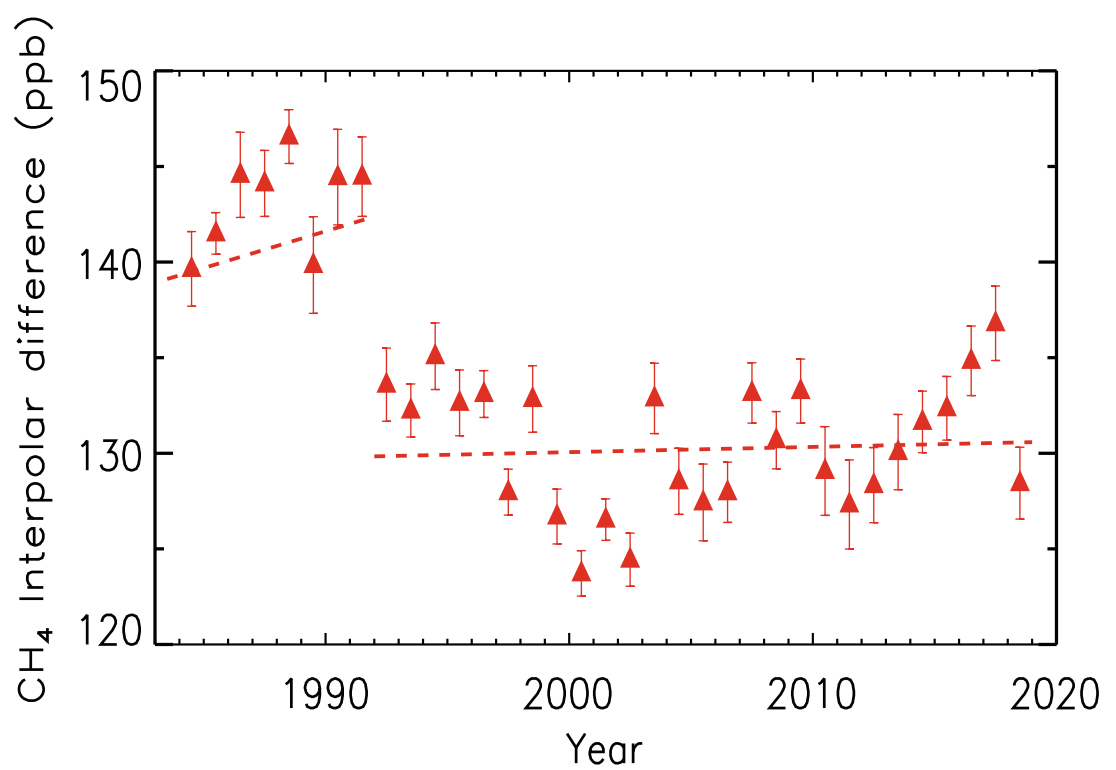

are about 1 year [103] so that the IPD cannot capture transport of low-latitude emissions to both polar regions within a year. Dimdore-Miles et al. [104] showed that relaxing the assumption of symmetric hemispheric transport results in significant interannual variability in the IPD that is not exclusively attributable to Arctic emissions.

We further explore the sensitivity of the IPD to changes in Arctic emissions using atmospheric transport modeling. It is important to force simulations with emissions that result in a realistic north-south gradient. For this reason, we use estimates of $\mathrm{CH}_{4}$ emissions from an atmospheric inversion (see the "Bottom-up Approaches" section) because the magnitude and spatiotemporal distribution of $\mathrm{CH}_{4}$ emissions are uncertain. In essence, emission estimates from inverse models have been adjusted in order to agree optimally with atmospheric observations. This is shown in the top panel of Fig. 4, where there is reasonable agreement between the observed and the IPD simulated using emissions estimated by the inversion. The bottom panel of Fig. 4 shows a comparison simulated annual average differences from the South Pole observations for each Artic network site. Two sets of simulations are shown, one using estimated emissions that have been adjusted to agree with observations by using an atmospheric inversion model and another using a constant repeating seasonal cycle of emissions north of $60^{\circ} \mathrm{N}$ constructed by averaging the estimated emissions. This figure shows that interannual variability in the IPD is dominated by atmospheric transport, not emissions. Furthermore, the long-term trend towards increasing IPD after 2005 is also dominated by atmospheric transport and likely is a reflection of increasing $\mathrm{CH}_{4}$ emissions from lower latitudes. In addition, some sites have a lot more variability than others, and there is a gradient between sites at lower and higher latitudes. Sites such as Iceland and those on the Aleutian Islands often see air from the North Pacific or Atlantic during the warm season and therefore do not always capture Arctic signals. Clearly, atmospheric transport complicates any attempt to directly link atmospheric concentration with emissions and must be accurately taken into account.

\section{Bottom-up Versus Top-down Estimates of Arctic Carbon Budgets}

Techniques for estimating carbon budgets can be classified as either "bottom-up" or "top-down" approaches. Bottom-up approaches (the "Bottom-up Approaches" section) make use of measurements or process-based models that are upscaled regionally. Examples include upscaling of the chamber and eddy flux observations to pan-Arctic scales (e.g., Ueyama et al. $[106,107])$ or global scales [108]. Process models of emissions are also a bottom-up approach since they model specific processes, are evaluated against flux observations, and used to predict regional fluxes (e.g., [109]). In contrast, top-down approaches use atmospheric observations to infer fluxes. Atmospheric observations reflect integrated contributions from fluxes encountered by air parcels as they are transported to measurement sites, including contributions from lower latitudes. These signals must be decomposed spatially and temporally to estimate fluxes at desired scales, generally by using an atmospheric transport model with realistic meteorology ("Atmospheric Inversions" section).

A perennial problem is disagreement between bottom-up and top-down estimates of Arctic carbon budgets. The AMAP Assessment of Arctic Methane ([110], Chapter 6) found that published estimates of emissions for various natural sources totaled over $70 \mathrm{TgCH}_{4}$ /year, almost three times top-down estimates that included both natural and anthropogenic Arctic emissions. At the global scale, Saunois et al. [111] highlighted 
Fig. 4 (Top) Annual average observed $\mathrm{CH}_{4}$ difference between an average of Arctic sites and the South Pole (the interpolar difference). The solid line shows the observed interpolar difference and the dashed line shows the simulated interpolar difference that uses flux estimates from an atmospheric inversion (an update of CarbonTracker- $\mathrm{CH}_{4},[105]$ ).

The comparison shows the agreement of the north-south gradient between the observations and the simulation using flux estimates from the inversion. Note that results differ from those shown in Fig. 3 due to different averaging and smoothing procedures. (Bottom) Annual average simulated $\mathrm{CH}_{4}$ difference by site between BRW, ZEP, ALT, ICE, and SHM and the South Pole. Solid lines are for $\mathrm{CH}_{4}$ simulated using flux estimates from an atmospheric inversion that vary interannually. Dashed lines show results from a simulation where a constant repeating annual cycle of average emissions was applied north of $60^{\circ} \mathrm{N}$. BRW is Barrow, Alaska; ALT is Alert, Nunavut, CA; ZEP is Zepplin, Ny-Alesund Svalbard, Norway; ICE is Storhofdi,

Vestmannaeyjar, Iceland; and

SHM is Shemya Island, Alaska
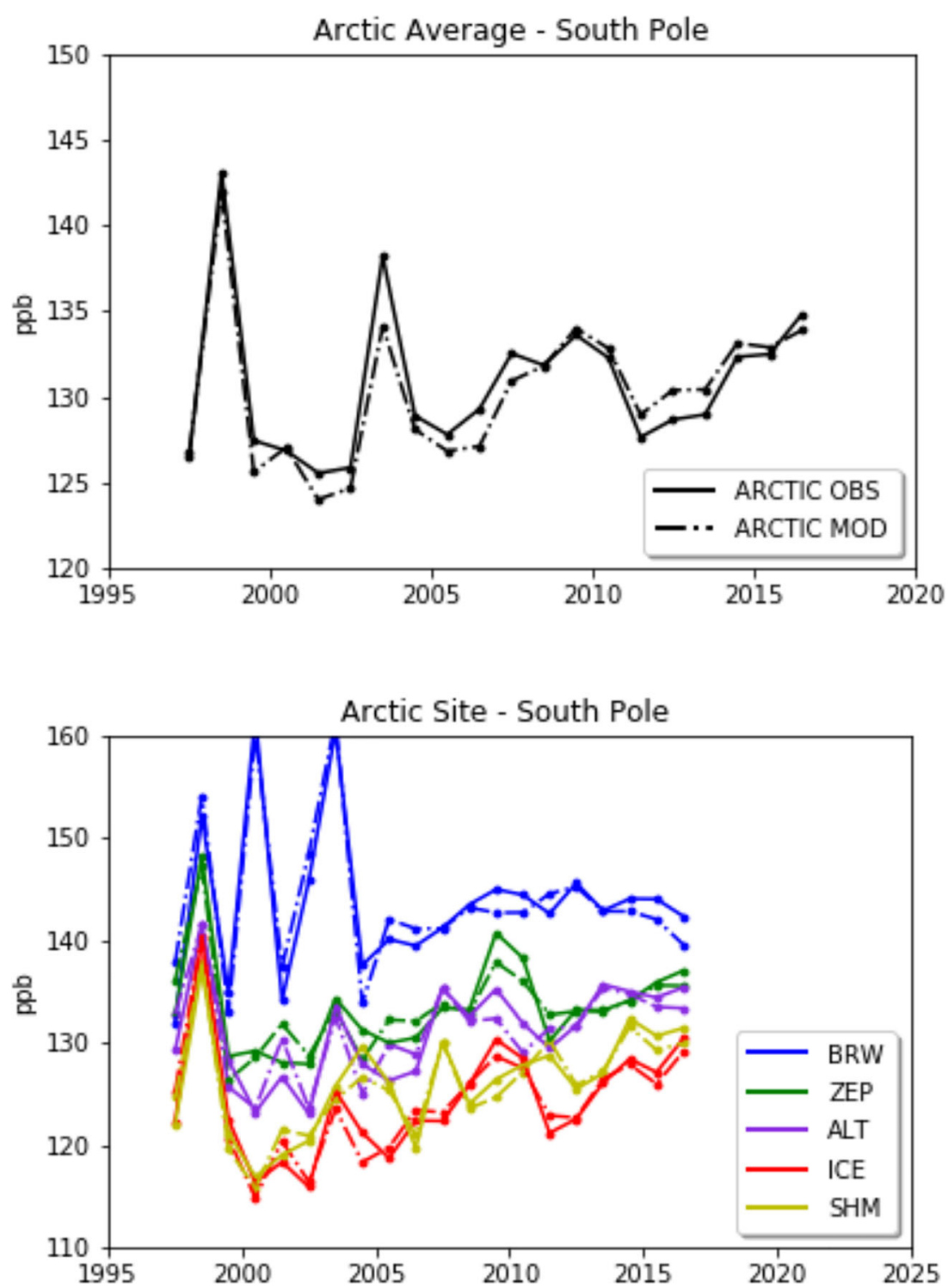

large discrepancies between estimates from bottom-up and top-down approaches. For example, for the category of "other natural emissions" (inland waters, geological emissions, oceans, termites, wild animals, and permafrost) bottom-up global estimates are $222 \mathrm{TgCH}_{4} /$ year (range 143-306 $\mathrm{TgCH}_{4}$ /year), while top-down estimates based on atmospheric observations are almost an order of magnitude smaller, 37 $\mathrm{TgCH}_{4} /$ year (21-50 $\mathrm{TgCH}_{4} /$ year) — an astounding difference! Saunois et al. [111] discussed a number of possible approaches that could lead to better agreement between topdown and bottom-up $\mathrm{CH}_{4}$ emission estimates, including increased spatial and temporal coverage of flux observations and their use for evaluation of models of natural $\mathrm{CH}_{4}$ fluxes, improving understanding of uncertainties due to atmospheric chemical destruction of $\mathrm{CH}_{4}$, more frequent updates of anthropogenic emission inventories and further development of wetland and lake datasets. They also point out that top-down estimates could be improved by incorporating stable isotope observations, for example, ${ }^{13} \mathrm{CH}_{4}$ which can help constrain the relative contributions from microbial and thermogenic emissions. Space-based column retrievals could also provide better spatial and temporal coverage although good quality retrievals can be relatively sparse at high latitudes due to solar geometry and long atmospheric path lengths. Uncertainty in atmospheric transport is an additional source of disagreement between bottom-up and top-down approaches, and Saunois et al. [111] advocate for the expanded use of vertical profile measurements to evaluate transport uncertainty.

\section{Bottom-up Approaches}

Bottom-up estimates of the Arctic carbon budget are typically achieved by upscaling observations or by simulating the carbon cycle with process models. These approaches have 
advantages and limitations. Process models can provide a large-scale view across decades but are limited by the accuracy of the climatic forcing and their representation of biogeochemical processes. Models need detailed spatial information about soil and vegetation that often is not available. Observations with flux chambers and eddy covariance towers are detailed snapshots of the carbon exchange of Arctic landscapes but severely restricted in time due to data outages or the short duration of field campaigns. Spatial coverage is also limited, and biases in pan-Arctic budget estimates can result from historic decisions to focus resources on establishing the importance and magnitude of the most significant carbon fluxes. Infrastructure limitations range from access or power availability, to meeting theoretical assumptions critical to the measurement; for example, the need to place flux towers in uniform terrain due to the complexities of atmospheric boundary layer dynamics. For $\mathrm{CH}_{4}$, flux observations may be made near-broad, uniform wetlands with fewer nearby ecologically diverse or drier upland environments, leading to a bias towards larger overall emissions in upscaled flux products [112].

$\mathrm{CH}_{4}$ emissions from lakes are an interesting example of the difficulties in extrapolating field observations. Based on studies of Siberian thermokarst lakes underlain by organic-rich yedoma soils, Walter et al. [113] estimated that ebullition could lead to significant local $\mathrm{CH}_{4}$ emissions $\left(3.8 \mathrm{TgCH}_{4} /\right.$ year for their study area). They also proposed that permafrost thaw over 25 years led to a nearly $60 \%$ increase in emissions from their study area. Having established the existence, local magnitude, persistence, and potential significance of a source that previously had not been considered in Arctic $\mathrm{CH}_{4}$ budgets, they estimated the pan-Arctic significance of their source: $24.2 \pm 10.5 \mathrm{TgCH}_{4} /$ year [114]. This amount would account for most of the emissions estimated from atmospheric observation using inversions [110], leaving no room in the Arctic budget for wetland emissions, anthropogenic emissions, and emissions from shallow continental shelves (assuming atmospheric inversions are correct and assuming sinks are not underestimated).

Wik et al. [115] pointed out the difficulties in scaling up emissions using techniques exploited by Walter et al. [113] to estimate emissions, namely using bubbles frozen in ice over winter. They pointed out that bubbles collected over winter cannot be used to scale up to continuous emissions; more transects are needed covering larger sections of lakes. Another complication is the possible oxidation of $\mathrm{CH}_{4}$ over time in trapped bubble air. A comprehensive study by Sepulvedo-Jauregui et al. [116] that looked at emissions of both $\mathrm{CH}_{4}$ and $\mathrm{CO}_{2}$ from high-latitude lakes found that $\mathrm{CH}_{4}$ in fresh bubbles was $33 \%$ higher than bubbles trapped in ice. Wik et al. [117] synthesized $\mathrm{CH}_{4}$ flux measurements from over 700 lakes located north of $50^{\circ} \mathrm{N}$ and used the satellite databased lake inventory of Verpoorter et al. [118] to estimate high northern latitude lake emissions. They found total emissions of $16.5 \pm 9.2 \mathrm{TgCH}_{4} /$ year, closer to top-down estimates. Wik et al. [117] also found that those post-glacial lakes, rather than thermokarst lakes, were likely to account for the largest share of emissions due to their larger surface areas, a conclusion that could vary depending on latitude range considered due to the distribution of permafrost and yedoma soils.

Wik et al. [117] upscaled site-specific flux observations by using spatial information about lake distributions from remote sensing data. A significant challenge for estimating $\mathrm{CH}_{4}$ emissions from lakes and wetlands is accurate information about where the $\mathrm{CH}_{4}$-producing environments are and how their distribution changes over time. Not all $\mathrm{CH}_{4}$-producing lakes and ponds are visible from space, and there is a continuum between small ponds and wetlands as pointed out by Holgerson and Raymond [119] who estimated that small ponds could contribute about $600 \mathrm{TgC} /$ year (both $\mathrm{CO}_{2}$ and $\mathrm{CH}_{4}$ ) to the global carbon budget. Furthermore, shallow water bodies, especially with vegetation growing in them, are among the highest $\mathrm{CH}_{4}$ emitters, and getting information about water depth from remote sensing observations is difficult. Thornton et al. [120] showed that the problems with definition of small water bodies and wetlands complicate the understanding of the relative contributions of lakes and wetlands and can lead to double-counting of emissions and bottom-up estimates that are biased high.

Even with the difficulties highlighted above, significant advances have been made over recent decades to estimate the carbon balance of the Arctic through simultaneous increase in observations and advancement of models, together with the assimilation of remote sensing data. By combining both observations and process models over the time period 1990-2006, McGuire et al. [121] estimated that Arctic tundra may be a sink of carbon of $-110 \mathrm{TgC}$ year ${ }^{-1}$, with an uncertainty ranging from a modest sink of $-291 \mathrm{TgC}$ year $^{-1}$ to a small source of $80 \mathrm{TgC}$ year $^{-1}$. They also estimated that the tundra biome is a $\mathrm{CH}_{4}$ source of $19 \mathrm{TgC} \mathrm{year}^{-1}$, with a lower and upper boundary of 8 and $29 \mathrm{TgC} \mathrm{year}^{-1}$. In this study, flux measurements were grouped into dry/mesic and wet vegetation classes. This distinction of water availability is important, since anoxic wet soils are a source of $\mathrm{CH}_{4}$ and exhibit lower respiration rates than drained oxygenated soils. Differences in water availability can, given the high heterogeneity of Arctic landscapes, lead to large contrasts in $\mathrm{CO}_{2}$ and $\mathrm{CH}_{4}$ fluxes across short distances $[122,123]$. Accurate knowledge of the distribution of wetlands and drained uplands, and their relative extents, is critical for accurate Arctic carbon budget estimates. The full climatic and ecological range present in the Arctic remains severely under-sampled, and this complicates constraining changes in the regional budget without the use of models or statistical methods.

Process models have, since the turn of the century, been instrumental in showing how carbon cycle feedbacks can 
accelerate climate change [124, 125]. The global models in use at the time had a basic representation of the terrestrial biosphere and early model development focused on the demography of tropical and mid-latitude forests, rather than the tundra biome and the permafrost region. Since then, significant advances have been made to make transient simulations of the Arctic carbon cycle, either forced by observations of past climate or under future climate scenarios. For example, terrestrial biosphere models have started to represent dwarf shrubs, sedges, and mosses (e.g., [126-129]) as well as the simulation of carbon stocks in permafrost and peatland soils (see e.g. [109, 130-132]). These advances have made it possible to explore changes in the Arctic carbon budget over time, and the potential for carbon cycle feedbacks.

A comparison of 10 terrestrial biosphere models showed a uniform increase in net primary production (NPP) over the period 1960-2009 across the permafrost region [133]. This increase was interpreted to be in response to higher temperatures and a fertilization effect of elevated $\mathrm{CO}_{2}$ concentrations. Individual models, however, showed large differences in gross primary production (GPP) - up to a factor of twohighlighting the large uncertainty in quantifying actual changes in the regional carbon budget. Moreover, it is unclear whether there will be a net uptake of $\mathrm{CO}_{2}$ with more climate warming since the release of carbon from permafrost soils may offset the increased uptake by vegetation. A comparison of 5 biogeochemical land models up to 2300 [71] showed a continued net uptake of carbon under the moderate warming scenario of RCP4.5, where litter input into the soil offset some of the permafrost carbon loss. However, model responses of vegetation and soil carbon strongly diverged under the high warming scenario RCP8.5- showing both a net release and net uptake of carbon by 2300 .

Besides diverging model results, it is important to note that there are a number of important processes missing from the models, or poorly implemented, which make future projections highly uncertain. Rapid thaw due to thermokarst has the potential to double permafrost carbon loss [134], but these processes play out at small scales and few implementations in land surface schemes exist [135]. Models strongly underestimate winter emissions, even though these may be large enough to offset the carbon uptake during the summer [107]. Extreme winter events have also been pinpointed as the cause of recent reductions in the growth of and carbon uptake by arctic vegetation $[52,136]$, which models fail to represent. Although a large uncertainty exists on the current and future importance of these factors, they have the capacity to reduce the uptake of $\mathrm{CO}_{2}$ by the Arctic and need to be a focus of model development.

Despite the uncertainty on the current and future sign of Arctic $\mathrm{CO}_{2}$ exchange, it is clear that the Arctic is a source of $\mathrm{CH}_{4}$, and there is a valid concern that these emissions may increase in the future. Much of this work has focused on wetlands, the largest natural $\mathrm{CH}_{4}$ source globally and in the Arctic. Early bottom-up studies of wetland $\mathrm{CH}_{4}$ emissions north of $50^{\circ} \mathrm{N}$ estimated that these emitted $15 \pm 10 \mathrm{TgC}$ year $^{-1}[137,138]$. The representation of $\mathrm{CH}_{4}$ production and consumption in these early model implementations was rudimentary and used fixed relationships with NPP, which is why they were mostly useful to estimate steady-state budgets rather than a response of wetland emissions to global warming. Improving upon these pioneering studies, Walter and Heimann [139] designed a methane model that was both process-based and climate-sensitive, and therefore useful for studies of global change. Production and consumption of $\mathrm{CH}_{4}$ were modeled as temperature-sensitive processes, and diffusion, plant transport, and ebullition were explicitly represented. Most methane schemes that are used in land surface models today incorporate some or all of the concepts introduced by the studies above (e.g., [140-144]). Moreover, new processes continue to be added, such as the inclusion of microbial mechanisms [145], sensitivity to $\mathrm{pH}$ [144], or improved oxidation of atmospheric $\mathrm{CH}_{4}$ in upland soils [146]. This progressive improvement of process representation has made methane models skillful when compared to field observations at the site level (e.g., [147]), but it remains challenging to derive accurate pan-Arctic budgets.

Since $\mathrm{CH}_{4}$ production is a temperature-sensitive process, global methane models typically simulate an increase in emissions with global warming [148]. The Arctic is the fastestwarming region in the world, partly due to the sea icealbedo effect, and models predict that this has led to a panArctic rise in $\mathrm{CH}_{4}$ emissions of a few $\mathrm{TgC}$ per year over the period 2005-2010 compared to the 1980s [141]. Regional drying, however, can compensate for such increases [149], which would explain why this signal has not been detected in the atmosphere [148]. Precipitation is expected to increase following sea ice retreat [150], but the moisture status of the surface will also depend on how evapotranspiration and drainage will change with temperature increase, snow cover loss, and permafrost thaw [30]. Whether the Arctic will become a larger source of $\mathrm{CH}_{4}$ depends not only on temperature but also at least as much on whether the region will become drier or wetter.

Knowledge of the location and extent of wetlands is paramount for estimating the pan-Arctic methane budget. To illustrate, modeled estimates of $\mathrm{CH}_{4}$ emissions can easily vary by a factor of 4 depending on the prescribed wetland product [151]. Besides, even if static wetland maps are perfect representations of the location of wetlands today, it cannot be expected that this extent will remain constant for decades, especially with changing climate. Accurate representations of the transient response of the wetland distribution to changing climate are needed to answer important questions about how carbon 
fluxes will evolve in the future. In recent years, this problem has been tackled by combining the knowledge of static wetland maps with the dynamics of surface inundation products derived from microwave remote sensing data [152]. Static maps provide useful information about the locations of wetlands and lakes at a particular point in time, while the surface inundation products vary over time but are typically not sensitive enough to capture saturated soil environments typical of wetlands. In combining these two types of information, a hopefully more comprehensive distribution of potential methane-producing environments can be produced that is useful for models. In practice, this is a movement away from an ecological definition of wetlands, such as vegetation composition, to a hybrid definition that relies on a physical property — water table — that varies throughout the year. This approach assumes that the land surface does not emit $\mathrm{CH}_{4}$ unless the water table is at or above the surface, even though $\mathrm{CH}_{4}$ emissions can continue when the water table is 10 to $15 \mathrm{~cm}$ below the surface [153]. It also ignores frozen soils while up to half of annual emissions from permafrost wetlands may originate from deeper unfrozen layers during the winter [154-156]. Wetland products that rely on surface inundation may therefore have limited value for the high latitudes, even though it is clear that such products could be a valuable advancement from a global modeling perspective.

Saunois et al. [111] determined global wetland emissions with thirteen biogeochemical models that used the latest remote sensing-based wetland area and dynamics dataset (WAD2M; Wetland Area Dynamics for Methane Modeling). For the region north of $60^{\circ} \mathrm{N}$, the models estimated that wetland $\mathrm{CH}_{4}$ emissions were 7 [2-14] $\mathrm{TgC}$ year $^{-1}$ in the time period 2008-2017. This is only about a quarter of the 26 [16-35] $\mathrm{TgC}_{\text {year }}{ }^{-1}$ previously estimated with many of the same models for the significantly smaller area of Arctic tundra [121]. The lower estimate is due to the subtraction of surface area covered by ponds and small lakes to avoid double-counting [120] as well as the above-mentioned high-latitude issues with surface inundation and frozen soils. Then again, even biogeochemical models that include microbial oxidation of $\mathrm{CH}_{4}$ in soils, especially drained upland soils, may underestimate the Arctic soil sink by as much as $\sim 4 \mathrm{TgC}_{\text {year }}{ }^{-1}$ [88]. This illustrates the importance of including all landscape types in assessing net emissions of methane.

While many advances have been made to simulate the biogeochemistry of wetlands and their extent, fewer studies have attempted to model $\mathrm{CH}_{4}$ emissions from other $\mathrm{CH}_{4}$ sources in the Arctic, such as lakes, geological sources, and the ocean. One of the few modeling studies that have estimated lake emissions with explicit representation of biogeochemical processes derived a pan-Arctic budget of 9 [5-13] TgC year ${ }^{-1}$ [157]. This compares reasonably well to bottom-up estimates based on extrapolations of flux measurements [111, 117, 158], but the continuous formation and drainage of thermokarst lakes in permafrost landscapes make it challenging to model emissions prognostically [159]. For the Arctic Ocean, detailed models exist that can simulate the evolution of gas hydrates and their emission to the atmosphere (e.g., [160]) but due to the slow thaw of subsea permafrost, which has been ongoing since these environments were submerged at the end of the last glacial, gas hydrates are not expected to destabilize until the next millennium [161]. Bottom-up estimates of geological emissions from the terrestrial Arctic are relatively small, $\sim 2 \mathrm{TgC}_{\text {year }}{ }^{-1}$ [162], but these emissions may respond to changes in permafrost thickness and disappearance of glaciers and ice caps.

Current bottom-up estimates of the Arctic carbon budget show that the region is a sink of $\mathrm{CO}_{2}$ but a source of $\mathrm{CH}_{4}$. Model simulations suggest that the strong rise in arctic temperatures and the thaw of permafrost may turn the region into a net source of carbon, although current projections for the twenty-first century do not indicate a release of greenhouse gases that is larger than anthropogenic emissions $[42,163]$. However, these projections are highly uncertain due to missing representation of thermokarst and key winter processes that may enhance arctic carbon loss. The risk of a large, uncontrolled, carbon cycle feedback from the Arctic remains a distinct possibility as long as anthropogenic emissions continue to rise and the amplified warming of the Arctic worsens.

\section{Atmospheric Inversions}

Atmospheric flux inversions use statistical optimization procedures and atmospheric transport models to estimate carbon fluxes that are in optimal agreement with both prior (first-guess) flux estimates and observations that are distributed in time and space (e.g., $[164,165])$. Prior flux estimates come from scaled-up field observations, process emission models, and economic inventories of anthropogenic emissions (livestock populations, fossil fuel production, etc.). Sparseness of observations, especially in the Arctic (and other regions such as the tropics), limits the spatial and temporal information that can be retrieved about fluxes, and therefore, prior flux estimates are used to stabilize an under-determined estimation problem. In regions where data are sparse or nonexistent, the estimated flux remains close to the prior estimate, producing posterior estimates that may be biased or not vary in time realistically.

A potential source of error for atmospheric inversions comes from uncertainty in transport of emissions by atmospheric circulation at both regional/global and local scales. Atmospheric transport models often have large 
grid boxes that range in size from 10 to $100 \mathrm{~s}$ of $\mathrm{km}$, such that coarse-resolution simulations are compared with point observations introducing representation errors. Although the original measurement network sites were chosen to sample air located far from strong local sources that are relatively easy for models to simulate (background atmospheric sites), representation errors become much more significant for air samples collected near sources, yet these samples offer potentially useful constraints of source variability in space and time. This problem is especially difficult for regions that have large spatial heterogeneity of sources. Increasing horizontal and vertical resolution of a transport model may improve the representation of transport in models and this has led to use of higher resolution $(10 \mathrm{~km})$ regional models for atmospheric inversions (e.g., [166]). Use of regional transport models requires specification of boundary conditions to capture the inflow of carbon from other latitudes or regions, however, and these are difficult to constrain with sparse observations.

Carbon fluxes estimated using an inverse model combine information coming from prior flux estimates, and information from observations. The relative weighting of these two types of observational constraints is dependent on uncertainties associated with the prior flux estimates and the observations. For observations, the uncertainties come from both the measurement uncertainty, which is generally very small for atmospheric in situ network observations, and the transport model error, which is difficult to quantify and much larger than the measurement uncertainty. This type of error is referred to as "modeldata mismatch error." For the prior fluxes, uncertainties are often difficult to quantify, although emission inventories sometimes include uncertainty estimates. A small prior uncertainty will lead to a solution that stays close to the prior fluxes and therefore may fail to capture actual flux variability. A small model-data mismatch error will result in a solution that tracks observations closely, possibly with unrealistic variability in flux estimates. A sparse network sampling the background atmosphere can still be useful for constraining some large-scale aspects of source distributions.

Figure 5 shows $\mathrm{CO}_{2}$ fluxes from 4 atmospheric inversions for the Boreal $\left(50^{\circ}-60^{\circ} \mathrm{N}\right)$ and the Arctic $\left(60^{\circ}-90^{\circ}\right.$ $\mathrm{N})$ zones. The top figures show the model average monthly $\mathrm{CO}_{2}$ fluxes and the range of the models (light blue area). For this study, we used inversions that were constrained only by in situ data. Retrievals from satellite-based instruments do exist that include some coverage of the Arctic in the summer; however, it is not currently possible to capture yearround carbon fluxes due to the viewing and solar geometry [171]. For the Boreal zone, there appears to be a jump in summertime uptake in the early 1990s; however, estimates prior to 1993 exist only for one of the 4 inversions, and differences between inversion systems could produce such a discontinuity. Note also that the inter-model range of the monthly estimates is quite large, a reflection of differences among the inversions; priors, transport models, prior errors used, and data selection. For both zones, it appears that the maximum summer uptake has been increasing since 1980, especially for the Boreal zone. This agrees with the observational analysis of Graven et al. [94], discussed further by Leonard et al. [172]. The bottom panels of Fig. 5 show annual average net $\mathrm{CO}_{2}$ fluxes from the inversion ensemble. The Boreal zone net $\mathrm{CO}_{2}$ flux is about $-0.3 \mathrm{PgC} /$ year, while the Arctic zone takes up only about $1 / 3$ this amount ($0.13 \mathrm{PgC} /$ year). There is a slight trend of increasing net uptake that is statistically significant for the Boreal zone ( $p=0.0003)$, but the small trend for the Arctic is not statistically significant. These results agree with the study of Welp et al. [173], who did not find significant trends north of $60^{\circ} \mathrm{N}$ from flux inversions, but small trends in the Boreal zone. Statistically significant trends in $\mathrm{CO}_{2}$ respiration were not found by the inversions used here, implying that the results of Commane et al. [98] are possibly localized to the vicinity of Barrow, Alaska, or that the inversions do not have the sensitivity to recover an increase in cold season respiration, or that increases in respiration are compensated for by another process, perhaps increased ocean uptake with lower sea ice cover.

Global inversions have been collected by the Global Carbon Project $\mathrm{CH}_{4}$ Project [111]. Figure 6 shows estimated natural emissions for 11 inversions that are constrained by in situ observations. The model spread is quite large due to differing transport models, priors, uncertainties, and observations. Interannual variability is seen in the flux estimates, and 2016 and 2017 appear to have significantly higher emissions. Emissions from the Boreal zone, which includes some large wetland complexes such as the Hudson Bay Lowlands in Canada and the southern part of the West Siberian lowlands, are about twice as large as for the Arctic zone. There is no statistically significant trend in emissions from the Boreal zone in contrast to Thompson et al. [97] who used a regional inverse model to find that $\mathrm{CH}_{4}$ emissions have been increasing north of $50^{\circ} \mathrm{N}$. For the Arctic zone, there does appear to be a small, but statistically significant trend towards increasing emissions of $\sim 0.2 \mathrm{TgCH}_{4}$ year.

Trends in fluxes estimated from inverse models should be considered with caution because the data used to constrain inversions is still very sparse and records do not yet cover the very long periods necessary to robustly detect trends. Biases in transport and prior fluxes are also possible sources of error in inversions. However, at present, inverse models are not suggesting large changes in the net carbon flux north of $50^{\circ} \mathrm{N}$ are occurring. 

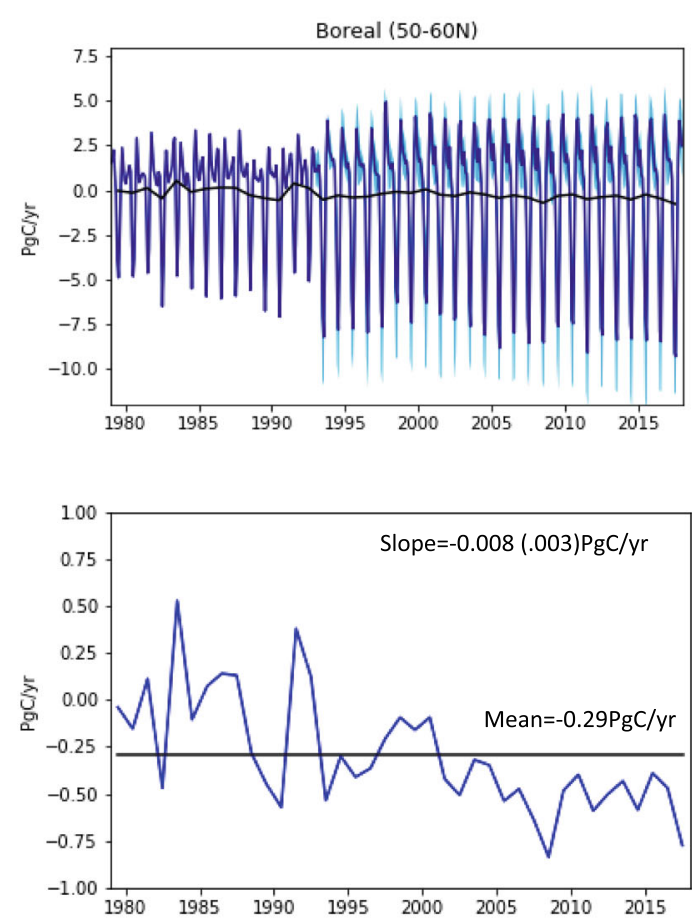

Fig. 5 (Top) Estimated monthly $\mathrm{CO}_{2}$ fluxes from 4 global inversions constrained by in situ data for the Boreal zone, defined here as $50^{\circ}-60^{\circ}$ $\mathrm{N}$, and the Arctic zone, defined here as $60^{\circ}-90^{\circ} \mathrm{N}$. The dark blue line shows average monthly fluxes in $\mathrm{PgC} /$ year, the light blue shaded area indicates the range of the 4 inverse models, and black line indicates the model average annual fluxes. Global inversions used are the Jena CarboScope ([167], s93_v4.2, bgc-jena.mpg.de/CarboScope.), the

\section{Cold Season Emissions}

Cold season $\mathrm{CO}_{2}$ emissions from Arctic soils are expected to increase due to increasing winter temperatures (the "Arctic Climate Change" section). Winter snowpack increases could further affect cold season emissions by insulating soils, keeping them warmer, and allowing more respiration. Using in situ atmospheric $\mathrm{CO}_{2}$ observations from Barrow, Alaska, Commane et al. [98] inferred increased emissions of $\mathrm{CO}_{2}$ early in the cold season. Natali et al. [107] synthesized both chamber and eddy covariance flux measurements for the cold season (October-April) from over 100 sites throughout the Arctic and Boreal high latitudes using machine learning techniques with a variety of environmental drivers (vegetation type, soil moisture, soil temperature). Their approach is similar to that used by Jung et al. [108] to produce the FLUXCOM product based on global eddy covariance flux tower observations. Natali et al. [107] found that $1.7 \mathrm{PgC} /$ year is emitted as $\mathrm{CO}_{2}$ from permafrost region soils during the cold season, an amount exceeding their modeled estimate of uptake during the warm season giving a net $\mathrm{CO}_{2}$ source. They also noted that they did not find any trends in cold season emissions for 2003-2017, which they attribute to a lack of circumpolar
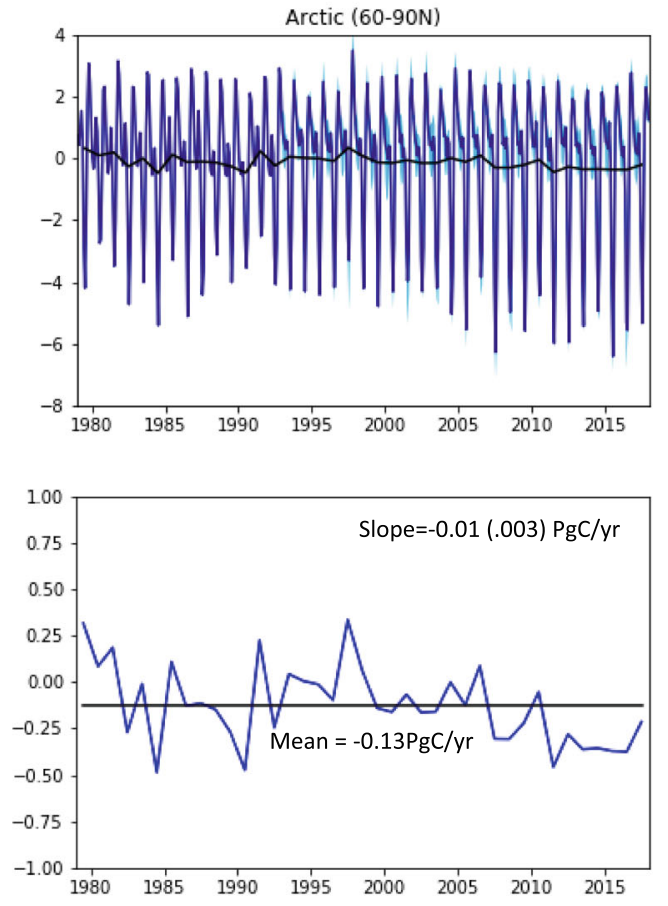

CAMS Greenhouse Gas Flux Inversion Product [168], https://apps. ecmwf.int/datasets/data/cams-ghg-inversions/), CarbonTracker ([169], CarbonTracker CT2017, http://carbontracker.noaa.gov) and CarbonTracker-EU ([170], http://www.carbontracker.eu). (Bottom) Annual average $\mathrm{CO}_{2}$ flux estimates for the 4 global inversions. The solid line shows the long-term mean. The slope refers to the slope of the linear least-squares fit line and its uncertainty

trends in the reanalysis data used in their algorithm. They did, however, find increases in winter respiration for sitelevel data from Alaska.

Figure 7 shows annual net $\mathrm{CO}_{2}$ exchange and cold/warm season fluxes for latitudes north of $60^{\circ} \mathrm{N}$ estimated using topdown and bottom-up approaches. Results from two atmospheric inversion systems (CarbonTracker and CarbonTracker-Europe) suggest that the Arctic is taking up more $\mathrm{CO}_{2}$ than is respired over a year. The prior flux estimates used in these inversions are the CASA-GFED model for CarbonTracker [174, 175] and SiB-CASA for CarbonTracker-Europe [176], both dependent on remotely sensed NDVI for estimating GPP. In the annual mean, both priors are nearly annually balanced with uptake about equal to respiration. The SiB4 terrestrial ecosystem model [177, 178], which has prognostic phenology and does not use NDVI, produces annual net $\mathrm{CO}_{2}$ fluxes that are similar to the prior estimates. FLUXCOM's annual net flux lies between the inversions and bottom-up models. During the warm season, FLUXCOM shows significantly less uptake than the other estimates and also less respiration during the cold season. Likewise, the inversions estimate less cold season respiration than their prior estimates or SiB4. During the cold season, 

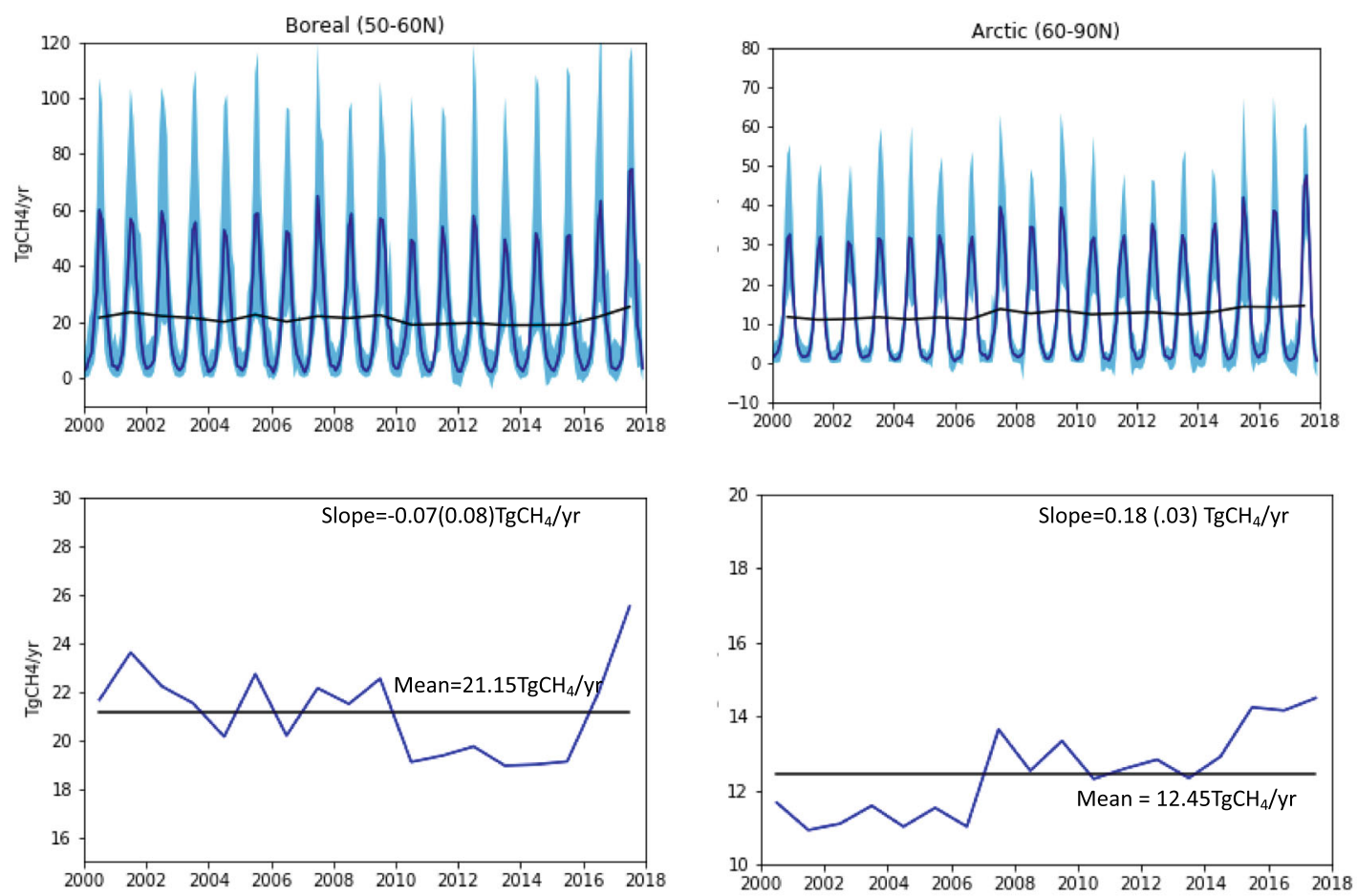

Fig. 6 (Top) Estimated natural Boreal zone $\left(50^{\circ}-60^{\circ} \mathrm{N}\right)$ and Arctic zone $\left(60^{\circ}-90^{\circ} \mathrm{N}\right) \mathrm{CH}_{4}$ emissions constrained by surface and in situ data for 11 inversions submitted to the GCP $\mathrm{CH}_{4}$ Project Budget Update [111]. For this figure, we focus on inversions that are constrained only by surface and in situ observations since remote sensing data is limited at high

emissions range from $\sim 0.8 \mathrm{PgC} /$ year for FLUXCOM to over $2.5 \mathrm{PgC} /$ year for SiB4. The estimate of Natali et al. [107], 1.6 $\mathrm{PgC} /$ year, falls between the inversions and the priors; however, their calculated warm season uptake ( - 1.0 PgC/year) is significantly smaller than the inverse estimates by at least a factor of 3. These results show the difficulty in interpretation of annual net $\mathrm{CO}_{2}$ fluxes since they are a balance of respiration and photosynthesis for which estimates from different methods can significantly diverge.

\section{Conclusions and Recommendations}

Multiple lines of observational evidence show that presently the remote Arctic is undergoing rapid environmental change. These changes have been directly linked to anthropogenic emissions [12].

Our understanding of Arctic climate tells us that there are important feedbacks in operation, such as between the cryosphere and the atmosphere, and between vegetation and atmospheric energy/moisture budgets. It is certain that changes in Arctic climate will drive changes in the carbon budget of the Arctic as vegetation changes, soils warm, fires increase, and wetlands evolve with permafrost thaw. Massive amounts

latitudes. The dark and light blue lines indicate the model mean and spread. The black line indicates the model average annual emissions. (Bottom) Annual average $\mathrm{CH}_{4}$ flux estimates for the 4 global inversions. The solid line shows the long-term mean. The slope refers to the slope of the linear least-squares fit line and its uncertainty

of carbon are stored in Arctic soils, and some fraction of this carbon is likely to be mobilized to the atmosphere and oceans with consequences that will feedback to affect global climate. This permafrost carbon feedback needs to be understood, quantified, and taken into account when considering climate mitigation (e.g., [179]), and formulating policy designed to ensure temperatures remain below particular thresholds. This will require a commitment to long-term pan-Arctic observations, as well as improvements in models used to help better understand the Arctic climate system.

Observations currently support a more active $\mathrm{CO}_{2}$ cycle in high northern latitude ecosystems with both enhanced productivity and increased respiration. Evidence points to increased uptake by boreal forests and Arctic ecosystems. Evidence also points towards increasing respiration, especially late in the warm season. On the other hand, there is currently no strong evidence of increased $\mathrm{CH}_{4}$ emissions, across the region, although we demonstrated here using atmospheric observations that small increases cannot be ruled out. Sweeney et al. [100] pointed out that given the widely observed temperature dependence of microbial production of $\mathrm{CH}_{4}$ in Arctic wetlands, the response of atmospheric $\mathrm{CH}_{4}$ to temperature increases appeared to be much smaller than expected. They attributed this lack of response to a lack of understanding of processes 

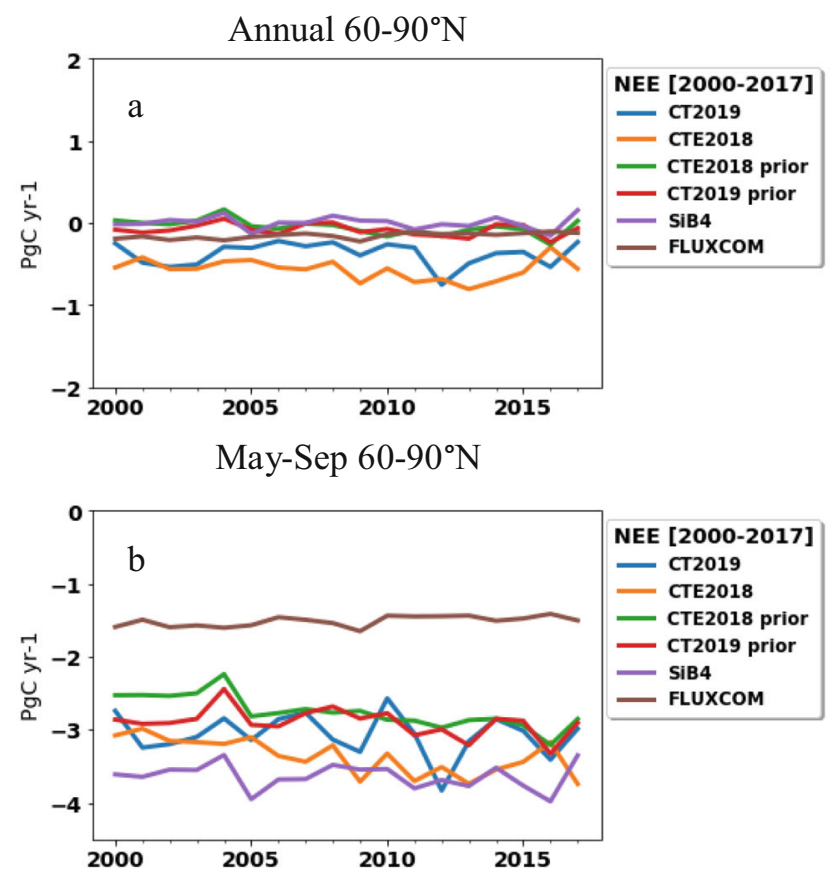

Oct-Apr $60-90^{\circ} \mathrm{N}$

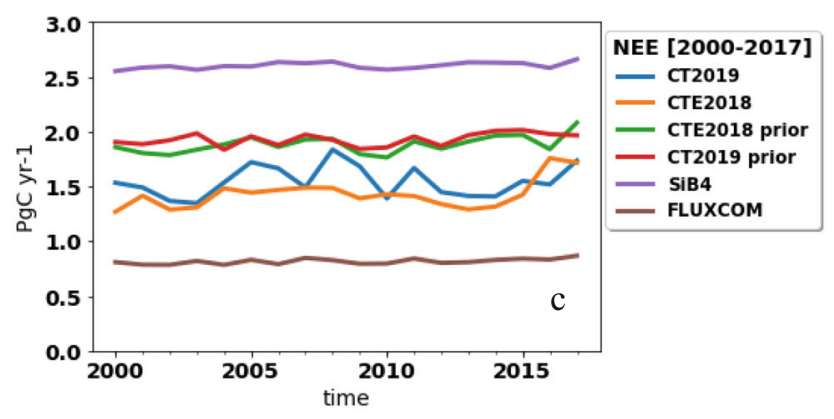

Fig. 7 a Annual net $\mathrm{CO}_{2}$ fluxes north of $60^{\circ} \mathrm{N}$ for two inverse models and their prior emissions, the SiB4 terrestrial ecosystem model, and FLUXCOM. b Warm season (May-September) $\mathrm{CO}_{2}$ fluxes. c Cold season (October-April) $\mathrm{CO}_{2}$ fluxes. Inversions shown are CarbonTracker ([169], CarbonTracker CT2019, http://carbontracker. noaa.gov) and CarbonTracker-EU (CTE2018, [170], http://www. carbontracker.eu). The prior flux estimates for both inverse models are based on terrestrial ecosystem models that use remote sensing observations to constrain GPP (e.g., NDVI). FLUXCOM is based on flux tower observations scaled to regional and global scales used machine learning techniques and ancillary data sets (for example, soil temperature). Note that negative fluxes indicate removal of carbon from the atmosphere and positive fluxes indicate emission to the atmosphere for improving projections of future emissions. Long-term observations provide the valuable opportunity to test predictive models and their sensitivity to change. Increasing observational coverage of flux measurements, in situ atmospheric sampling, and remote sensing data from satellites and committing to maintaining data records over decades will improve our understanding of the Arctic carbon cycle and how it is changing over time.

Acknowledgments The authors would like to acknowledge Marielle Saunois and all of those who submitted their inverse modeling results to the Global Carbon Project for use of their results in this paper. We also thank the CarboScope, CAMS Greenhouse Gas Flux Inversion Product, CarbonTracker-Europe, and CarbonTracker projects for allowing us to use their results in this paper. We thank Atmospheric Chemistry Carbon Cycle and Climate, NOAA Climate Program Office for their support of Leonard.

Author Contributions All authors contributed to the development of this paper by contributing text. The paper concept and the original draft were developed by Bruhwiler.

Funding Bruhwiler is employed by the NOAA Global Monitoring Laboratory. PIP was supported by the Natural Environment Research Council (grant no. NE/N015916/1). FJWP was supported by the Norwegian Research Council under grant agreement 274711, and the Swedish Research Council under registration no. 2017-05268. Leonard is supported by funding from the NOAA Climate Program Office, AC4 program.

Data Availability All data used in this study are freely available for download from https://www.esrl.noaa.gov/gmd/.

\section{Compliance with Ethical Standards}

Conflict of Interest The authors declare that they have no conflict of interest.

Open Access This article is licensed under a Creative Commons Attribution 4.0 International License, which permits use, sharing, adaptation, distribution and reproduction in any medium or format, as long as you give appropriate credit to the original author(s) and the source, provide a link to the Creative Commons licence, and indicate if changes were made. The images or other third party material in this article are included in the article's Creative Commons licence, unless indicated otherwise in a credit line to the material. If material is not included in the article's Creative Commons licence and your intended use is not permitted by statutory regulation or exceeds the permitted use, you will need to obtain permission directly from the copyright holder. To view a copy of this licence, visit http://creativecommons.org/licenses/by/4.0/. leading to emissions. However, it is also possible that microbial consumption of atmospheric $\mathrm{CH}_{4}$ in drier upland soils is also increasing as temperatures rise and that this process has been significantly underestimated as proposed by $\mathrm{Oh}$ et al. [88]. Alternatively, a reduction in wetland extent and increased lake drainage may have played a role.

Finally, we point out that long-term observations help us to understand what has or is changing, but they are also critical

\section{References}

1. Meredith MM, Sommerkorn S, Cassotta C, Derksen A, Ekaykin A, Hollowed et al. In: H.-O. Pörtner, D.C. Roberts, V. MassonDelmotte, P. Zhai, M. Tignor, E. Poloczanska, K. Mintenbeck, A. Alegría, M. Nicolai, A. Okem, J. Petzold, B. Rama, N.M. Weyer (eds.) Polar Regions. IPCC Special Report on the Ocean and Cryosphere in a Changing Climate 2019. https://www.ipcc.ch/ srocc/chapter/chapter-3-2/. 
2. Overland JE, Hanna E, Hanssen-Bauer I, Kim S-J, Walsh JE, Wang M, et al. In: The NOAA Arctic Report Card, Surface Air Temperature 2019, https://arctic.noaa.gov/Report-Card/ReportCard 2019/ArtMID/7916/ArticleID/835/Surface-AirTemperature.

3. Goosse H, Kay JE, Armour KC, et al. Quantifying climate feedbacks in polar regions. Nat Commun. 2018;9(2018):1919. https:// doi.org/10.1038/s41467-018-04173-0.

4. Kay JE, et al. Recent advances in Arctic cloud and climate research. Curr Clim Change Rep. 2016;2:159.

5. Pithan F, Mauritsen T. Arctic amplification dominated by temperature feedbacks in contemporary climate models. Nat Geosci. 2014;7:181-4.

6. Qu X, Hall A. What controls the strength of snow-albedo feedback? J Clim. 2007;20:3971-81.

7. Stuecker MF, Bitz CM, Armour KC, et al. Polar amplification dominated by local forcing and feedbacks. Nat Clim Chang. 2018;8:1076-81. https://doi.org/10.1038/s41558-018-0339-y.

8. Taylor PC, et al. A decomposition of feedback contributions to polar warming amplification. J Clim. 2013;26:7023-43.

9. Graversen RG, Wang M. Polar amplification in a coupled climate model with locked albedo. Clim Dyn. 2009;33:629-43. https:// doi.org/10.1007/s00382-009-0535-6.

10. Box JE, Colgan WT, Christensen TR, Schmidt NM, Lund M, Parmentier F-JW, et al. Key indicators of Arctic climate change, 1971-2017. Environ Res Lett. 2019;14:045010.

11. Gillett N, Stone D, Stott P, Nozawa T, Karpechko AY, Hegerl GC, et al. Attribution of polar warming to human influence. Nat Geosci. 2008;1:750-4. https://doi.org/10.1038/ngeo338.

12. Najafi M, Zwiers F, Gillett N. Attribution of Arctic temperature change to greenhouse-gas and aerosol influences. Nat Clim Chang. 2015;5:246-9. https://doi.org/10.1038/nclimate2524.

13. Serreze MC, Stroeve J. Arctic sea ice trends, variability and implications for seasonal ice forecasting. Philos Trans R Soc London, Ser A. 2015;373:20140159. https://doi.org/10.1098/ rsta.2014.0159.

14. Blunden J, Arndt DS. State of the climate in 2018. Bull Am Meteorol Soc. 2019;100:Si-S306. https://doi.org/10.1175/ 2019BAMSStateoftheClimate.1.

15. Stroeve J, Notz D. Changing state of Arctic Sea ice across all seasons. Environ Res Lett. 2018;13(10):103001. https://doi.org/ 10.1088/1748-9326/aade56.

16. Halfar J, Adey WH, Kronz A, Hetzinger S, Edinger E, Fitzhugh WW. Arctic sea-ice decline archived by multicentury annualresolution record from crustose coralline algal proxy. PNAS. 2013;110(49):19737-41. https://doi.org/10.1073/pnas. 1313775110

17. Notz, D. and J. Stroeve (2016) Observed Arctic sea-ice loss directly follows anthropogenic $\mathrm{CO}_{2}$ emission. Science, 354, Issue 6313, pp. 747-750. DOI: https://doi.org/10.1126/science. aag2345.

18. Notz D, Stroeve J. The trajectory towards a seasonally ice-free Arctic Ocean. Curr Clim Change Rep. 2018;4:407-16. https:// doi.org/10.1007/s40641-018-0113-2.

19. Timmermans M-L, Toole J, Krishfield R. Warming of interior Arctic Ocean linked to sea ice losses at the basin margin. Sci Adv. 2018;4(8):eaat6773. https://doi.org/10.1126/sciadv.aat6773.

20. Woodgate RA. Increases in the Pacific inflow to the Arctic from 1990 to 2015, and insights into seasonal trends and driving mechanisms from year-round Bering Strait mooring data. Prog Oceanogr. 2018;160:124-54. https://doi.org/10.1016/j.pocean. 2017.12.007.

21. Mudryk LR, Kushner PJ, Derksen C, Thackeray C. Snow cover response to temperature in observational and climate model ensembles. Geophys Res Lett. 2017;44:919-26. https://doi.org/10. 1002/2016GL071789.
22. Mudryk L., R. Brown, C. Derksen, K. Luojus, B. Decharme, and S. Helfrich (2019) Terrestrial snow cover, Richter-Menge, J., M. L. Druckenmiller, and M. Jeffries, Eds.: Arctic Report Card 2019, https://www.arctic.noaa.gov/Report-Card.

23. AMAP Assessment 2017: Snow, water, ice and permafrost in the Arctic (SWIPA) (2017), Arctic Monitoring and Assessment Programme (AMAP), Oslo, Norway. xiv $+269 \mathrm{pp}$.

24. Vihma T, Screen J, Tjernström M, Newton B, Zhang X, Popova $\mathrm{V}$, et al. The atmospheric role in the Arctic water cycle: A review on processes, past and future changes, and their impacts. J Geophys Res Biogeosci. 2016;121:586-620. https://doi.org/10. 1002/2015JG003132.

25. Wendler G, Gordon T, Stuefer M. On the precipitation and precipitation change in Alaska. Atmosphere. 2017;8(12):253. https:// doi.org/10.3390/atmos8120253.

26. Peterson BJ, Holmes RM, McClelland JW, Vörösmarty CJ, Lammers RB, Shiklomanov AI, et al. Increasing river discharge to the Arctic Ocean. Science. 2002;298:217. https://doi.org/10. 1126/science.1077445.

27. Vihma T, Screen J, Tjernström M, Newton B, Zhang X, Popova $\mathrm{V}$, et al. The atmospheric role in the Arctic water cycle: a review on processes, past and future changes, and their impacts. J Geophys Res G: Biogeosci. 2016;121:586-620. https://doi.org/ 10.1002/2015JG003132.

28. Zhang K, Kimball JS, Mu QZ, Jones LA, Goetz SJ, Running SW. Satellite based analysis of northern ET trends and associated changes in the regional water balance from 1983 to 2005 . J Hydrol. 2009;379:92-110.

29. Biskaborn BK, Smith SL, Noetzli J, et al. Permafrost is warming at a global scale. Nat Commun. 2019;10:264. https://doi.org/10. 1038/s41467-018-08240-4.

30. Liljedahl A, Boike J, Daanen R, Fedorov AN, Frost GV, Grosse $\mathrm{G}$, et al. Pan-Arctic ice-wedge degradation in warming permafrost and its influence on tundra hydrology. Nat Geosci. 2016;9:312-8. https://doi.org/10.1038/ngeo2674.

31. Farquharson LM, Romanovsky VE, Cable WL, Walker DA, Kokelj SV, Nicolsky D. Climate change drives widespread and rapid thermokarst development in very cold permafrost in the Canadian High Arctic. Geophys Res Lett. 2019;46:6681-9. https://doi.org/10.1029/2019GL082187.

32. Olefeldt D, Goswami S, Grosse G, Hayes D, Hugelius G, Kuhry $\mathrm{P}$, et al. Circumpolar distribution and carbon storage of thermokarst landscapes. Nat Commun. 2016;7:13043. https:// doi.org/10.1038/ncomms 13043

33. Nitze I, Grosse G, Jones BM, et al. Remote sensing quantifies widespread abundance of permafrost region disturbances across the Arctic and Subarctic. Nat Commun. 2018;9:5423.

34. Rudy ACA, Lamoureux SF, Kokelj SV, Smith IR, England JH. Accelerating thermokarst transforms ice-cored terrain triggering a down- stream cascade to the ocean. Geophys Res Lett. 2017;44: 11,080-7. https://doi.org/10.1002/2017GL074912.

35. Jones BM, et al. Modern thermokarst lake dynamics in the continuous permafrost zone, northern Seward Peninsula, Alaska. J Geophys Res G : Biogeosci. 2011;116:G00M03.

36. Baltzer JL, Veness T, Chasmer LE, Sniderhan AE, Quinton WL. Forests on thawing permafrost: fragmentation, edge effects, and net forest loss. Glob Change Biol. 2014;20:824-34. https://doi. org/10.1111/gcb.12349.

37. Romanovsky, V., Isaksen, K., Drozdov, D., Anisimov, O., Instanes, A., Leibman, M., et al. (2017) Changing permafrost and its impacts. In: AMAP, snow, water, ice and permafrost in the Arctic (SWIPA) 2018. Oslo, Norway: Arctic monitoring and assessment Programme (AMAP), pp. 65-102.

38. Chang K-Y, Riley WJ, Crill PM, Grant RF, Rich VI, Saleska SR. Large carbon cycle sensitivities to climate across a permafrost 
thaw gradient in subarctic Sweden. Cryosphere. 2019;13:647-63. https://oi.org/10.5194/tc-13-647-2019.

39. Parmentier FJW, Christensen TR, Rysgaard S, Bendtsen J, Glud $\mathrm{RN}$, Else B, et al. A synthesis of the arctic terrestrial and marine carbon cycles under pressure from a dwindling cryosphere. Ambio. 2017;46(1):53-69. https://doi.org/10.1007/s13280-0160872-8.

40. Tarnocai C, Canadell JG, Schuur EAG, Kuhry P, Mazhitova G, Zimov S. Soil organic carbon pools in the northern circumpolar permafrost region. Glob Biogeochem Cycles. 2009;23:GB2023. https://doi.org/10.1029/2008GB003327.

41. Hugelius G, Strauss J, Zubrzycki S, Harden JW, Schuur EAG, Ping C-L, et al. Estimated stocks of circumpolar permafrost carbon with quantified uncertainty ranges and identified data gaps. Biogeosciences. 2014;11:6573-93. https://doi.org/10.5194/bg11-6573-2014.

42. Schuur E, McGuire A, Schädel C, Grosse G, Harden JW, Hayes DJ, et al. Climate change and the permafrost carbon feedback. Nature. 2015;520:171-9. https://doi.org/10.1038/nature14338.

43. Ruppel CD, Kessler JD. The interaction of climate change and methane hydrates. Rev Geophys. 2017;55:126-68. https://doi. org/10.1002/2016RG000534.

44. Romanovskii NN, Hubberten HW, Gavrilov AV, Eliseeva AA, Tipenko GS. Offshore permafrost and gas hydrate stability zone on the shelf of East Siberian seas. Geo-Mar Lett. 2005;25:167-82.

45. Dmitrenko IA, Kirillov SA, Tremblay LB, Kassens H, Anisimov OA, Lavrov SA, et al. Recent changes in shelf hydrography in the Siberian Arctic: potential for subsea permafrost instability. J of Geophys Res C: Oceans. 2011;116(C10):C10027. https://doi. org/10.1029/2011JC007218.

46. Ferré B, Mienert J, Feseker T. Ocean temperature variability for the past 60 years on the Norwegian-Svalbard margin influences gas hydrate stability on human time scales. J Geophys Res C: Oceans. 2012;117:C10017. https://doi.org/10.1029/ 2012JC008300.

47. Stranne C, O'Regan M, Jakobsson M. Overestimating climate warming-induced methane gas escape from the seafloor by neglecting multiphase flow dynamics. Geophys Res Lett. 2016;43:8703-12. https://doi.org/10.1002/2016GL070049.

48. Elmendorf S, Henry G, Hollister R, et al. Plot-scale evidence of tundra vegetation change and links to recent summer warming. Nat Clim Chang. 2012;2:453-7. https://doi.org/10.1038/ nclimate 1465.

49. Myers-Smith IH, Hik DS. Climate warming as a driver of tundra shrubline advance. J Ecol doi. 2018. https://doi.org/10.1111/13652745.12817.

50. Myers-Smith I, Elmendorf S, Beck P, et al. Climate sensitivity of shrub growth across the tundra biome. Nat Clim Chang. 2015;5: 887-91. https://doi.org/10.1038/nclimate2697.

51. Bhatt US, Walker DA, Raynolds MK, Bieniek PA, Epstein HE, Comiso JC, et al. Changing seasonality of pan-Arctic tundra vegetation in relationship to climatic variables. Environ Res Lett. 2017;12:055003.

52. Myers-Smith I, Kerby JT, Phoenix GK, Bjerke JW, Epstein HE, Assmann JJ, et al. Complexity revealed in the greening of the Arctic. Nat Clim Chang. 2020;10:106-17. https://doi.org/10. 1038/s41558-019-0688-1.

53. van der Werf GR, Randerson JT, Giglio L, van Leeuwen TT, Chen Y, Rogers BM, et al. Global fire emissions estimates during 1997-2016. Earth Syst Sci Data. 2017;9:697-720. https://doi.org/ 10.5194/essd-9-697-2017.

54. Amiro BD, et al. Direct carbon emissions from Canadian forest fires, 1959-1999. Can J For Res. 2001;31:512-25.

55. Kasischke ES, Johnstone JF. Variation in post-fire organic layer thickness in a black spruce forest complex in Interior Alaska and its effects on soil temperature and moisture. Can J For Res. 2005;35:2164-77.

56. Yi S, et al. Interactions between soil, thermal and hydrological dynamics in the response of Alaska ecosystems to fire disturbance. J Geophys Res G: Biogeosci. 2009;114:G02015.

57. Turetsky M, Kane E, Harden J, Ottmar RD, Mannies KL, Hoy E, et al. Recent acceleration of biomass burning and carbon losses in Alaskan forests and peatlands. Nat Geosci. 2011;4:27-31. https:// doi.org/10.1038/ngeo1027.

58. McCarty JL, Smith TEL, Turetsky MR. Arctic fires re-emerging. Nat Geosci. 2020;13:658-60. https://doi.org/10.1038/s41561020-00645-5.

59. Bond-Lamberty B, Peckham SD, Ahl DE, Gower ST. Fire as the dominant driver of central Canadian boreal forest carbon balance. Nature. 2007;450(7166):89-92. https://doi.org/10.1038/ nature 06272 .

60. Kelly R, Chipman ML, Higuera PE, Stefanova I, Brubaker LB, $\mathrm{Hu}$ FS. Recent burning of boreal forests exceeds fire regime limits of the past 10,000 years. PNAS. 2013. https://doi.org/10.1073/ pnas. 1305069110.

61. Coops NC, Hermosilla T, Wulder MA, White JC, Bolton DK. A thirty year, fine-scale, characterization of area burned in Canadian forests shows evidence of regionally increasing trends in the last decade. PLoS One. 2018;13(5):e0197218. https://doi.org/10. 1371/journal.pone.0197218.

62. Ponomarev EI, Kharuk VI, Ranson KJ. Wildfires dynamics in Siberian larch forests. Forests. 2016;7:125.

63. Andela N, Morton DC, Giglio L, Chen Y, van der Werf GR, Kasibhatla PS, et al. A human-driven decline in global burned area. Science. 2017;30:356-6345, 1356-1362. https://doi.org/10. 1126/science.aal4108.

64. Veraverbeke S, Rogers B, Goulden M, Jandt RR, Miller CE, Wiggins EB, et al. Lightning as a major driver of recent large fire years in North American boreal forests. Nat Clim Chang. 2017;7: 529-34. https://doi.org/10.1038/nclimate3329.

65. SIMIP Community (2020) Arctic sea ice in CMIP6. Geophys Res Lett, 47, e2019GL086749. https://doi.org/10.1029/ 2019GL086749

66. Lantuit H, Overduin PP, Wetterich S. Recent progress regarding permafrost coasts. Permafr Periglac Process. 2013;24:120-30. https://doi.org/10.1002/ppp.1777.

67. Bintanja RK, Van der Wiel EC, Van der Linden J, Reusen L, Bogerd $\mathrm{F}$ et al. Strong future increases in Arctic precipitation variability linked to poleward moisture transport. Sci Adv,.2020 12FEB2020:EAAX6869.

68. Hansen BB, Isaksen K, Benestad RE, Kohler J, Pederson ÅØ, Loe LE, et al. Warmer and wetter winters: characteristics and implications of an extreme weather event in the High Arctic. Environ Res Lett. 2014;9:11. https://doi.org/10.1088/1748-9326/9/11/114021.

69. Peters G, Andrew R, Boden T, et al. The challenge to keep global warming below $2{ }^{\circ} \mathrm{C}$. Nat Clim Chang. 2013;3(2013):4-6. https:// doi.org/10.1038/nclimate1783.

70. Overland JE, Wang M, Walsh JE, Stroeve JC. Future Arctic climate changes: adaptation and mitigation time scales. Earth's Future. 2014. https://doi.org/10.1002/2013EF000162.

71. McGuire AD, Lawrence DM, Koven C, Clein JS, Burke E, Chen $\mathrm{G}$, et al. Dependence of the evolution of carbon dynamics in the northern permafrost region on the trajectory of climate change. PNAS. 2018;30:201719903. https://doi.org/10.1073/pnas. 1719903115.

72. Nitzbon J, Westermann S, Langer M, Martin LCP, Strauss J, Laboor S, et al. Fast response of cold ice-rich permafrost in northeast Siberia to a warming climate. Nat Commun. 2020;11(1): 2201. https://doi.org/10.1038/s41467-020-15725-8. 
73. Pastick NJ, et al. Historical and projected trends in landscape drivers affecting carbon dynamics in Alaska. Ecol Appl. 2017;27(5):1383-402. https://doi.org/10.1002/eap.1538.

74. Young AM, Higuera PE, Duffy PA, Hu FS. Climatic thresholds shape northern high-latitude fire regimes and imply vulnerability to future climate change. Ecography. 2017;40(5):606-17. https:// doi.org/10.1111/ecog.02205.

75. Walter Anthony K, et al. $21^{\text {st }}$ century modeled permafrost carbon emissions accelerated by abrupt thaw beneath lakes. Nat Commun. 2018;9(1):3262. https://doi.org/10.1038/s41467-01805738-0.

76. Pearson RG, Phillips SJ, Loranty MM, Beck PSA, Damoulas T, Knight SJ, et al. Shifts in Arctic vegetation and associated feedbacks under climate change. Nat Clim Chang. 2013;3:673-7.

77. Swann AL, Fung IY, Levis S, Bonan GB, Doney SC. Changes in Arctic vegetation amplify high-latitude warming through the greenhouse effect. PNAS. 2009;107:4,1295-300 www.pnas.org/ cgi/doi/10.1073/pnas.0913846107.

78. Parmentier FJW, Christensen TR, Sørensen LL, Rysgaard S, McGuire AD, Miller PA, et al. The impact of a lower sea-ice extent on Arctic greenhouse-gas exchange. Nat Clim Chang. 2013;3:195-202.

79. Terhaar J, Orr JC, Ethé C, Regnier P, Bopp L. Simulated Arctic Ocean response to doubling of riverine carbon and nutrient delivery. Glob Biogeochem Cycles. 2019;33:1048-70. https://doi.org/ 10.1029/2019GB006200.

80. Shakhova N, Semiletov I, Salyuk A, Yusupov V, Kosmach D, Gustafsson Ö. Extensive methane venting to the atmosphere from sediments of the East Siberian Arctic Shelf. Science. 2010;327: 1246.

81. Berchet A, Bousquet P, Pison I, Locatelli R, Chevallier F, Paris J$\mathrm{D}$, et al. Atmospheric constraints on the methane emissions from the East Siberian Shelf. Atmos Chem Phys. 2016;16:4147-57. https://doi.org/10.5194/acp-16-4147-2016.

82. Thornton BF, Prytherch J, Andersson K, Brooks IM, Salisbury DJ, Tjernström M, et al. Shipborne eddy covariance observations of methane fluxes constrain Arctic sea emissions. Sci Adv. 2020;6(5):eaay7934. https://doi.org/10.1126/sciadv.aay.7934.

83. Piao $\mathrm{S}$, Ciais $\mathrm{P}$, Friedlingstein $\mathrm{P}$, et al. Net carbon dioxide losses of northern ecosystems in response to autumn warming. Nature. 2008;451:49-52. https://doi.org/10.1038/nature06444.

84. Lund M, Falk JM, Friborg T, Mbufong HN, Sigsgaard C, Soegaard $\mathrm{H}$, et al. Trends in $\mathrm{CO}_{2}$ exchange in a high Arctic tundra heath, 2000-2010. J Geophys Res G: Biogeosci. 2012;117(G2): G02001. https://doi.org/10.1029/2011JG001901.

85. Parmentier F-JW, van Huissteden J, van der Molen MK, Schaepman-Strub G, Karsanaev SA, Maximov TC, et al. Spatial and temporal dynamics in eddy covariance observations of methane fluxes at a tundra site in northeastern Siberia. J Geophys Res Biogeosci. 2011a;116(G3):G03016. https://doi.org/10.1029/ 2010JG001637.

86. Roach J, Griffith B, Verbyla D, Jones J. Mechanisms influencing changes in lake area in Alaskan boreal forest. Glob Chang Biol. 2011;17:2567-83. https://doi.org/10.1111/j.1365-2486.2011. 02446.x.

87. Lawrence DM, Koven CD, Swenson SC, Riley WJ, Slater AG. Permafrost thaw and resulting soil moisture changes regulate highlatitude $\mathrm{CO}_{2}$ and $\mathrm{CH}_{4}$ emissions. Environ Res Lett. 2015;10(9): 094011.

88. Oh Y, Zhuang Q, Liu L, Welp LR, Lau MCY, Onstott TC, et al. Reduced net methane emissions due to microbial methane oxidation in a warmer Arctic. Nat Clim Chang. 2020;10(4):317-21. https://doi.org/10.1038/s41558-020-0734-z.

89. Whalen SC, Reeburgh WS, Barber VA. Oxidation of methane in boreal forest soils: a comparison of seven measures.
Biogeochemistry. 1992;16:181-211. https://doi.org/10.1007/ BF00002818.

90. Myhre GD, Shindell F.-M, Bréon W, Collins J, Fuglestvedt J, Huang D et al. Anthropogenic and natural radiative forcing. In: Stocker, T.F., D. Qin, G.-K. Plattner, M. Tignor, S.K. Allen, J. Boschung, A. Nauels, Y. Xia, V. Bex and P.M. Midgley (eds.) Climate Change 2013: The physical science basis. Contribution of Working Group I to the Fifth Assessment Report of the Intergovernmental Panel on Climate Change, Cambridge University Press, Cambridge, United Kingdom and New York, NY, USA. 2013

91. Turetsky MR, Abbott BW, Jones MC, Walter Anthony K, Olefeldt D, Schuur EAG, et al. Permafrost collapse is accelerating carbon release. Nature. 2019;569:32-4. https://doi.org/10.1038/ d41586-019-01313-4.

92. Koven CD, Schuur EAG, Schädel C, Bohn TJ, Burke EJ, Chen G, et al. A simplified, data-constrained approach to estimate the permafrost carbon-climate feedback. Phil Trans R Soc London: Ser A. 2015;373:20140423. https://doi.org/10.1098/rsta.2014.0423.

93. Schuur EAG, Abbott BW, Bowden WB, Brovkin V, Camill P, et al. Expert assessment of vulnerability of permafrost carbon to climate change. Clim Chang. 2013;119:359-74.

94. Graven HD, Keeling RF, Piper SC, Patra PK, Stephens BB, Wofsy SC, et al. Enhanced seasonal exchange of $\mathrm{CO}_{2}$ by northern ecosystems since 1960. Science. 2013;341(6150):1085-9. https:// doi.org/10.1126/science.1239207.

95. Barlow JM, Palmer PI, Bruhwiler LM, Tans P. Analysis of $\mathrm{CO}_{2}$ mole fraction data: first evidence of large-scale changes in $\mathrm{CO}_{2}$ uptake at high northern latitudes. Atmos Chem Phys. 2015;15: 13739-58. https://doi.org/10.5194/acp-15-13739-2015.

96. Forkel M, Carvalhais N, Rodenbeck C, Keeling R, Heimann M, Thonicke $\mathrm{K}$, et al. Enhanced seasonal $\mathrm{CO}_{2}$ exchange caused by amplified plant productivity in northern ecosystems. Science. 2016;351(6274):696-9. https://doi.org/10.1126/science.aac4971.

97. Thompson RL, Sasakawa M, Machida T, Aalto T, Worthy D, Lavric JV, et al. Methane fluxes in the high northern latitudes for 2005-2013 estimated using a Bayesian atmospheric inversion. Atmos Chem Phys. 2017;17:3553-72. https://doi.org/10.5194/ acp-17-3553-2017.12.

98. Commane R, Lindaas J, Benmergui J, Luus KA, Chang RY-W, Daube $\mathrm{BC}$, et al. Increasing early winter $\mathrm{CO}_{2}$ from Alaskan tundra. PNAS. 2017;114(21):5361-6. https://doi.org/10.1073/pnas. 1618567114

99. Jeong SJ, Bloom AA, Schimel D, Sweeney C, Parazoo N.C Medvigy, et al. Accelerating rates of Arctic carbon cycling revealed by long-term atmospheric $\mathrm{CO}_{2}$ measurements. Sci. Adv 2018 4(7) eaao1167. https://doi.org/10.1126/sciadv.aao1167.

100. Sweeney C, Dlugokencky E, Miller CE, Wofsy S, Karion A, Dinardo $\mathrm{S}$, et al. No significant increase in long-term $\mathrm{CH}_{4}$ emissions on North Slope of Alaska despite significant increase in air temperature. Geophys Res Lett. 2016;43(12):6604-11. https://doi. org/10.1002/2016GL069292.

101. Dlugokencky EJ, Houweling S, Bruhwiler L, Masarie KA, Lang PM, Miller JB, et al. Atmospheric methane levels off: temporary pause or a new steady state? Geophys Res Lett. 2003;30:1992. https://doi.org/10.1029/2003GL018126.

102. Dlugokencky EJ, Nisbet EG, Fisher R, Lowry D. Global atmospheric methane: budget changes and dangers. Philos Trans R Soc London Ser A. 2011; 369: 2058-2072. https://doi.org/10.1098/ rsta.2010.0341.

103. Holzer M, Waugh DW. Interhemispheric transit time distributions and path-dependent lifetimes constrained by measurements of $\mathrm{SF}_{6}$, CFCs, and CFC replacements. Geophys Res Lett. 2015;42: 4581-9. https://doi.org/10.1002/2015GL064172.

104. Dimdore-Miles OB, Palmer PI, Bruhwiler LP. Detecting changes in Arctic methane emissions: limitations of the inter-polar 
difference of atmospheric mole fractions. Atmos Chem Phys. 2018;18:17895-907. https://doi.org/10.5194/acp-18-17895-2018.

105. Bruhwiler L, Dlugokencky E, Masarie K, Ishizawa M, Andrews A, Miller J, et al. CarbonTracker- $\mathrm{CH}_{4}$ : an assimilation system for estimating emissions of atmospheric methane. Atmos Chem Phys. 2014;14:8269-93. https://doi.org/10.5194/acp-14-8269-2014.

106. Ueyama M, Ichii K, Iwata H, Euskirchen ES, Zona D, Rocha AV, et al. Upscaling terrestrial carbon dioxide fluxes in Alaska with satellite remote sensing and support vector regression. J Geophys Res Biogeosci. 2013;118:1266-81. https://doi.org/10.1002/jgrg. 20095.

107. Natali SM, Watts JD, Rogers BM, Potter S, Ludwig SM, Selbmann A-K, et al. Large loss of $\mathrm{CO}_{2}$ in winter observed across the northern permafrost region. Nat Clim Chang. 2019;9(11): 852-7. https://doi.org/10.1038/s41558-019-0592-8.

108. Jung M, Reichstein M, Schwalm CR, Huntingford C, Sitch S, Ahlström A, et al. Compensatory water effects link yearly global land $\mathrm{CO}_{2}$ sink changes to temperature. Nature. 2017;541(7638): 516-20. https://doi.org/10.1038/nature20780.

109. Qiu C, Zhu D, Ciais P, Guenet B, Krinner G, Peng S, et al. ORCHIDEE-PEAT (revision 4596), a model for northern peatland $\mathrm{CO}_{2}$, water, and energy fluxes on daily to annual scales. Geosci Model Dev. 2018;11(2):497-519. https://doi.org/10.5194/ gmd-11-497-2018.

110. AMAP Assessment 2015: Methane as an Arctic climate forcer. Arctic Monitoring and Assessment Programme (AMAP), Oslo, Norway. vii +139 pp.

111. Saunois M, Stavert AR, Poulter B, Bousquet P, Canadell JG, Jackson RB, et al. The global methane budget 2000-2017. Earth Syst Sci Data. 2020. https://doi.org/10.5194/essd-2019-128.

112. Jørgensen CJ, Lund Johansen KM, Westergaard-Nielsen A, Elberling B. Net regional methane sink in High Arctic soils of northeast Greenland. Nat Geosci. 2014;8:20-3. https://doi.org/ 10.1038/NGEO2305.

113. Walter KM, Zimov SA, Chanton JP, Verbyla D, Chapin FS. Methane bubbling from Siberian Thaw Lakes as a positive feedback to climate warming. Nature. 2006;443:71-5. https://doi.org/ 10.1038/nature 05040 .

114. Walter KM, Smith LC, Chapin FS. Methane bubbling from northern lakes: present and future contributions to the global methane budget. Phil Trans R Soc London: Ser A. 2007;365:1657-76. https://doi.org/10.1098/rsta.2007.2036.

115. Wik M, Crill PM, Bastviken D, Danielsson Å, Norbäck E. Bubbles trapped in arctic lake ice: potential implications for methane emissions. J Geophys Res. 2011;116:G03044. https://doi.org/ 10.1029/2011JG001761.

116. Sepulveda-Jauregui A, Walter Anthony KM, Martinez-Cruz K, Greene S, Thalasso F. Methane and carbon dioxide emissions from 40 lakes along a north-south latitudinal transect in Alaska. Biogeosciences. 2015;12:3197-223. https://doi.org/10.5194/bg12-3197-2015.

117. Wik M, Varner R, Anthony KW, MacIntyre S, Bastviken D. Climate-sensitive northern lakes and ponds are critical components of methane release. Nat Geosci. 2016;9:99-105. https:/ doi.org/10.1038/ngeo2578.

118. Verpoorter C, Kutser T, Seekell DA, Tranvik LJ. A global inventory of lakes based on high-resolution satellite imagery. Geophys Res Lett. 2014;41:6396-402.

119. Holgerson M, Raymond P. Large contribution to inland water $\mathrm{CO}_{2}$ and $\mathrm{CH}_{4}$ emissions from very small ponds. Nat Geosci. 2016;9:222-6. https://doi.org/10.1038/ngeo2654.

120. Thornton BF, Wik M, Crill PM. Double-counting challenges the accuracy of high-latitude methane inventories. Geophys Res Lett. 2016;43:12,569-77. https://doi.org/10.1002/2016GL071772.

121. McGuire AD, Christensen TR, Hayes D, Heroult A, Euskirchen E, Kimball JS, et al. An assessment of the carbon balance of Arctic tundra: comparisons among observations, process models, and atmospheric inversions. Biogeosciences. 2012;9(8):3185-204. https://doi.org/10.5194/bg-9-3185-2012.

122. Parmentier F-JW, van der Molen MK, van Huissteden J, Karsanaev SA, Kononov AV, Suzdalov DA, et al. Longer growing seasons do not increase net carbon uptake in the northeastern Siberian tundra. J Geophys Res G: Biogeosci. 2011b;116(G4): G04013. https://doi.org/10.1029/2011JG001653.

123. Pirk N, Sievers J, Mertes J, Parmentier FJW, Mastepanov M, Christensen TR. Spatial variability of $\mathrm{CO}_{2}$ uptake in polygonal tundra: assessing low-frequency disturbances in eddy covariance flux estimates. Biogeosciences. 2017;14(12):3157-69. https://doi. org/10.5194/bg-14-3157-2017.

124. Cox PM, Betts RA, Jones CD, Spall SA, Totterdell IJ. Acceleration of global warming due to carbon-cycle feedbacks in a coupled climate model. Nature. 2000;408(6809):184-7. https://doi.org/10.1038/35041539.

125. Friedlingstein P, Bopp L, Ciais P, Dufresne J-L, Fairhead L, LeTreut $\mathrm{H}$, et al. Positive feedback between future climate change and the carbon cycle. Geophys Res Lett. 2001;28(8):1543-6. https://doi.org/10.1029/2000GL012015.

126. Chadburn S, Burke E, Essery R, Boike J, Langer M, Heikenfeld $\mathrm{M}$, et al. An improved representation of physical permafrost dynamics in the JULES land-surface model. Geosci Model Dev. 2015;8(5):1493-508. https://doi.org/10.5194/gmd-8-1493-2015.

127. Druel A, Ciais P, Krinner G, Peylin P. Modeling the vegetation dynamics of northern shrubs and mosses in the ORCHIDEE land surface model. J Adv Model Earth Sy. 2019;11(7):2020-35 10/ gg $7 \mathrm{kdn}$.

128. Hayes DJ, McGuire AD, Kicklighter DW, Gurney KR, Burnside TJ, Melillo JM. Is the northern high-latitude land-based $\mathrm{CO}_{2}$ sink weakening? Global Biogeochem Cy. 2011;25(3):GB3018. https:// doi.org/10.1029/2010GB003813.

129. Wolf A, Callaghan TV, Larson K. Future changes in vegetation and ecosystem function of the Barents Region. Clim Chang. 2008;87(1-2):51-73. https://doi.org/10.1007/s10584-007-93424.

130. Chadburn SE, Krinner G, Porada P, Bartsch A, Beer C, Belelli Marchesini L, et al. Carbon stocks and fluxes in the high latitudes: using site-level data to evaluate Earth system models. Biogeosciences. 2017;14(22):5143-69. https://doi.org/10.5194/ bg-14-5143-2017.

131. Ekici A, Beer C, Hagemann S, Boike J, Langer M, Hauck C. Simulating high-latitude permafrost regions by the JSBACH terrestrial ecosystem model. Geosci Model Dev. 2014;7(2):631-47 10/f24qvk.

132. Wania R, Ross I, Prentice IC. Integrating peatlands and permafrost into a dynamic global vegetation model: 1 . Evaluation and sensitivity of physical land surface processes. Glob Biogeochem Cy. 2009;23(3):GB3014. https://doi.org/10.1029/2008GB003412.

133. Xia J, McGuire AD, Lawrence D, Burke E, Chen G, Chen X, et al. Terrestrial ecosystem model performance in simulating productivity and its vulnerability to climate change in the northern permafrost region. J Geophys Res G: Biogeosci. 2017;122(2):430-46. https://doi.org/10.1002/2016JG003384 2017.

134. Turetsky MR, Abbott BW, Jones MC, Anthony KW, Olefeldt D, Schuur EAG, et al. Carbon release through abrupt permafrost thaw. Nat Geosci. 2020;13(2):138-43. https://doi.org/10.1038/ s41561-019-0526-0.

135. Aas KS, Martin L, Nitzbon J, Langer M, Boike J, Lee H, et al. Thaw processes in ice-rich permafrost landscapes represented with laterally coupled tiles in a land surface model. Cryosphere. 2019;13(2):591-609. https://doi.org/10.5194/tc-13-591-2019.

136. Parmentier F-JW, Rasse DP, Lund M, Bjerke JW, Drake BG, Weldon S, et al. Vulnerability and resilience of the carbon exchange of a subarctic peatland to an extreme winter event. 
Environ Res Lett. 2018;13(6):065009. https://doi.org/10.1088/ 1748-9326/aabff3.

137. Cao MK, Marshall S, Gregson K. Global carbon exchange and methane emissions from natural wetlands: application of a process-based model. J Geophys Res Atmos. 1996;101(D9): 14399-414. https://doi.org/10.1029/96JD00219.

138. Christensen TR, Prentice IC, Kaplan J, Haxeltine A, Sitch S. Methane flux from northern wetlands and tundra - an ecosystem source modelling approach. Tellus Series B. 1996;48(5):652-61.

139. Walter BP, Heimann M. A process-based, climate-sensitive model to derive methane emissions from natural wetlands: application to five wetland sites, sensitivity to model parameters, and climate. Glob Biogeochem Cy. 2000;14(3):745-65. https://doi.org/10. 1029/1999GB001204.

140. Kaiser S, Göckede M, Castro-Morales K, Knoblauch C, Ekici A, Kleinen T, et al. Process-based modelling of the methane balance in periglacial landscapes (JSBACH-methane). Geosci Model Dev. 2017;10(1):333-58. https://doi.org/10.5194/gmd-10-333-2017.

141. Parmentier F-JW, Zhang W, Mi Y, Zhu X, Huissteden J, Hayes DJ, et al. Rising methane emissions from northern wetlands associated with sea ice decline. Geophys Res Lett. 2015;42(17):7214 22. https://doi.org/10.1002/2015GL065013.

142. Wania R, Melton JR, Hodson EL, Poulter B, Ringeval B, Spahni $\mathrm{R}$, et al. Present state of global wetland extent and wetland methane modelling: methodology of a model inter-comparison project (WETCHIMP). Geosci Model Dev. 2013;6(3):617-41. https:// doi.org/10.5194/gmd-6-617-2013.

143. Wania R, Ross I, Prentice IC. Implementation and evaluation of a new methane model within a dynamic global vegetation model: LPJ-WHyMe v1.3.1. Geosci Model Dev. 2010;3(2):565-84. https://doi.org/10.5194/gmd-3-565-2010.

144. Zhuang Q, Melillo JM, Kicklighter DW, Prinn RG, McGuire AD, Steudler PA, et al. Methane fluxes between terrestrial ecosystems and the atmosphere at northern high latitudes during the past century: a retrospective analysis with a process-based biogeochemistry model. Glob Biogeochem Cy. 2004;18(3):GB3010. https://doi. org/10.1029/2004GB002239.

145. Xu X, Elias DA, Graham DE, Phelps TJ, Carroll SL, Wullschleger $\mathrm{SD}$, et al. A microbial functional group-based module for simulating methane production and consumption: application to an incubated permafrost soil. J Geophys Res G: Biogeosci. 2015;120(7): 1315-33. https://doi.org/10.1002/2015JG002935.

146. Oh Y, Stackhouse B, Lau MCY, Xu X, Truman AT, Moch J, et al. A scalable model for methane consumption in arctic mineral soils. Geophys Res Lett. 2016;43:5143-50. https://doi.org/10.1002/ 2016 GL069049.

147. Treat CC, Marushchak ME, Voigt C, Zhang Y, Tan Z, Zhuang Q, et al. Tundra landscape heterogeneity, not interannual variability, controls the decadal regional carbon balance in the Western Russian Arctic. Glob Chang Biol. 2018b;24(11):5188-204. https://doi.org/10.1111/gcb.14421

148. Saunois M, Bousquet P, Poulter B, Peregon A, Ciais P, Canadell $\mathrm{JG}$, et al. Variability and quasi-decadal changes in the methane budget over the period 2000-2012. Atmos Chem Phys. 2017;17(18):11135-61. https://doi.org/10.5194/acp-17-111352017

149. Watts JD, Kimball JS, Bartsch A, McDonald KC. Surface water inundation in the boreal-Arctic: potential impacts on regional methane emissions. Environ Res Lett. 2014;9(7):075001. https:// doi.org/10.1088/1748-9326/9/7/075001.

150. Bintanja R, Selten FM. Future increases in Arctic precipitation linked to local evaporation and sea-ice retreat. Nature. 2014;509(7501):479-82. https://doi.org/10.1038/nature13259.

151. Petrescu AMR, van Beek LPH, van Huissteden J, Prigent C, Sachs $\mathrm{T}$, Corradi CAR, et al. Modeling regional to global $\mathrm{CH}_{4}$ emissions of boreal and arctic wetlands. Global Biogeochem Cy. 2010;24(4): GB4009. https://doi.org/10.1029/2009GB003610.

152. Poulter B, Bousquet P, Canadell JG, Ciais P, Peregon A, Saunois M, et al. Global wetland contribution to 2000-2012 atmospheric methane growth rate dynamics. Environ Res Lett. 2017;12(9): 094013. https://doi.org/10.1088/1748-9326/aa8391.

153. Olefeldt D, Turetsky MR, Crill PM, McGuire AD. Environmental and physical controls on northern terrestrial methane emissions across permafrost zones. Glob Chang Biol. 2013;19(2):589-603. https://doi.org/10.1111/gcb.12071.

154. Mastepanov M, Sigsgaard C, Dlugokencky EJ, Houweling S, Ström L, Tamstorf MP, et al. Large tundra methane burst during onset of freezing. Nature. 2008;456(7222):628-30. https://doi. org/10.1038/nature07464

155. Treat CC, Bloom AA, Marushchak ME. Nongrowing season methane emissions-a significant component of annual emissions across northern ecosystems. Glob Chang Biol. 2018a;44:163. https://doi.org/10.1111/gcb.14137.

156. Zona D, Gioli B, Commane R, Lindaas J, Wofsy SC, Miller CE, et al. Cold season emissions dominate the Arctic tundra methane budget. PNAS. 2016;113(1):40-5. https://doi.org/10.1073/pnas. 1516017113

157. Tan Z, Zhuang Q. Arctic lakes are continuous methane sources to the atmosphere under warming conditions. Environ Res Lett. 2015;10(5):054016. https://doi.org/10.1088/1748-9326/10/5/ 054016.

158. Bastviken D, Tranvik LJ, Downing JA, Crill PM, Enrich-Prast A. Freshwater methane emissions offset the continental carbon sink. Science. 2011;331(6013):50-0. https://doi.org/10.1126/science. 1196808.

159. van Huissteden J, Berrittella C, Parmentier FJW, Mi Y, Maximov TC, Dolman AJ. Methane emissions from permafrost thaw lakes limited by lake drainage. Nat Clim Chang. 2011;1(2):119-23. https://doi.org/10.1038/nclimate1101.

160. Archer D. A model of the methane cycle, permafrost, and hydrology of the Siberian continental margin. Biogeosciences. 2015;12(10):2953-74. https://doi.org/10.5194/bg-12-2953-2015.

161. Angelopoulos M, Overduin PP, Miesner F, Grigoriev MN, Vasiliev AA. Recent advances in the study of Arctic submarine permafrost. Permafrost Periglac. 2020;31:442-53. https://doi.org/ 10.1002/ppp.2061.

162. Walter Anthony KM, Anthony P, Grosse G, Chanton J. Geologic methane seeps along boundaries of Arctic permafrost thaw and melting glaciers. Nat Geosci. 2012;5(6):419-26. https://doi.org/ 10.1038/ngeo1480.

163. Christensen TR, Arora VK, Gauss M, Höglund-Isaksson L, Parmentier F-JW. Tracing the climate signal: mitigation of anthropogenic methane emissions can outweigh a large Arctic natural emission increase. Sci Report. 2019;9(1):1146. https://doi.org/10. 1038/s41598-018-37719-9.

164. Enting I. Estimation and inversion across the spectrum of carbon cycle modelling. AIMS Geosciences. 2018;4:126-43.

165. Tarantola A. Inverse problem theory methods for data fitting and model parameter estimation. New York: Elsevier Sci; 1987.

166. Miller, S.M., C.E. Miller, R. Commane, R.Y.-W. Chang, S.J. Dinardo, J.M. Henderson, A. Karion, J. Lindaas, J.R. Melton, J.B. Miller, C. Sweeney, S.C. Wofsy, A.M. Michalak (2016) A multiyear estimate of methane fluxes in Alaska from CARVE atmospheric observations. Global Biogeochem. Cycles, 30 (10), 1441-1453. doi:https://doi.org/10.1002/2016GB005419.

167. Rödenbeck C. Estimating $\mathrm{CO} 2$ sources and sinks from atmospheric mixing ratio measurements using a global inversion of atmospheric transport, Technical Report 6. Jena, Germany: Max Planck Institute for Biogeochemistry; 2005.

168. Chevallier F. Validation report for the inverted CO2 fluxes, v18r1. CAMS deliverable CAMS73_2018SC1_D73.1.4.1-2017- 
v0_201812; 2018. https://atmosphere.copernicus.eu/sites/default/ files/2019-01/CAMS73_2018SC1_D73.1.4.1-2017-v0_201812_ v1 final.pdf.

169. Peters W, Jacobson AR, Sweeney C, Andrews AE, Conway TJ, Masarie K, et al. An atmospheric perspective on North American carbon dioxide exchange: CarbonTracker. PNAS. 2007;104(48): 18925-30. https://doi.org/10.1073/pnas.0708986104.

170. van der Laan-Luijkx IT, van der Velde IR, van der Veen E, Tsuruta A, Stanislawska K, Babenhauserheide A, et al. The CarbonTracker Data Assimilation Shell (CTDAS) v1.0: implementation and global carbon balance 2001-2015. Geosci Model Dev. 2017;10(7):2785-800. https://oi.org/10.5194/gmd-10-2785-2017.

171. Parazoo NC, Commane R, Wofsy SC, Koven CD, Sweeney C, Lawrence DM, et al. PNAS. 2016;113(28):7733-8. https://doi. org/10.1073/pnas. 1601085113 .

172. Leonard, M. et al. (2020) Examining the global terrestrial carbon cycle using 'top-down' and 'bottom-up' models. in prep.

173. Welp LR, Patra PK, Rödenbeck C, Nemani R, Bi J, Piper SC, et al. Increasing summer net $\mathrm{CO}_{2}$ uptake in high northern ecosystems inferred from atmospheric inversions and comparisons to remotesensing NDVI. Atmos Chem Phys. 2016;16:9047-66. https://doi. org/10.5194/acp-16-9047-2016.

174. Potter CS, Randerson JT, Field CB, Matson PA, Vitousek PM, Mooney HA, et al. Terrestrial ecosystem production: a process model based on global satellite and surface data. Global Biogeochem Cycles. 1993;7(4):811-41. https://doi.org/10.1029/ $93 \mathrm{~GB} 02725$.
175. Randerson JT, Van Der Werf GR, Giglio L, Collatz GJ, Kasibhatla PS. Global fire emissions database, version 4.1 (GFEDv4). ORNL DAAC. 2015. https://doi.org/10.3334/ ORNLDAAC/1293.

176. Schaefer K, Collatz GJ, Tans P, Denning AS, Baker I, Berry J, et al. Combined simple biosphere/Carnegie-Ames-Stanford approach terrestrial carbon cycle model. J Geophys Res G: Biogeosci. 2008;113(G3):G03034. https://doi.org/10.1029/ 2007JG000603.

177. Haynes K, Baker IT, Denning S, Stöckli R, Schaefer K, Lokupitiya EY, et al. Representing grasslands using dynamic prognostic phenology based on biological growth stages: 1 . Implementation in the Simple Biosphere Model (SiB4). J Adv Model Earth Syst. 2019a;11:4423-39. https://doi.org/10.1029/ 2018MS001540.

178. Haynes KD, Baker IT, Denning AS, Wolf S, Wohlfahrt G, Kiely $\mathrm{G}$, et al. Representing grasslands using dynamic prognostic phenology based on biological growth stages: 2 . Carbon cycling. J Adv Model Earth Syst. 2019b;11:4440-65. https://doi.org/10. 1029/2018MS001541.

179. Schaefer K, Lantuit H, Romanovsky VE, Schuur EAG, Witt R. The impact of permafrost carbon feedback on global climate. Environ Res Lett. 2014;9:085003. https://doi.org/10.1088/17489326/9/8/085003.

Publisher's Note Springer Nature remains neutral with regard to jurisdictional claims in published maps and institutional affiliations. 